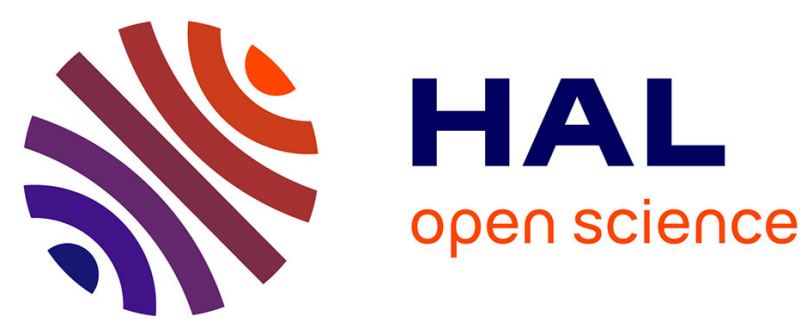

\title{
Establishment of occupation chronicles in Grotte Mandrin using sooted concretions: Rethinking the Middle to Upper Paleolithic transition
}

Ségolène Vandevelde, Jacques Élie Brochier, Christophe Petit, Ludovic Slimak

\section{To cite this version:}

Ségolène Vandevelde, Jacques Élie Brochier, Christophe Petit, Ludovic Slimak. Establishment of occupation chronicles in Grotte Mandrin using sooted concretions: Rethinking the Middle to Upper Paleolithic transition. Journal of Human Evolution, 2017, 112, pp.70-78. 10.1016/j.jhevol.2017.07.016 . halshs-01610057

\section{HAL Id: halshs-01610057 \\ https://shs.hal.science/halshs-01610057}

Submitted on 15 Aug 2018

HAL is a multi-disciplinary open access archive for the deposit and dissemination of scientific research documents, whether they are published or not. The documents may come from teaching and research institutions in France or abroad, or from public or private research centers.
L'archive ouverte pluridisciplinaire HAL, est destinée au dépôt et à la diffusion de documents scientifiques de niveau recherche, publiés ou non, émanant des établissements d'enseignement et de recherche français ou étrangers, des laboratoires publics ou privés. 


\title{
Journal of Human Evolution
}

\author{
http://dx.doi.org/10.1016/j.jhevol.2017.07.016
}

\section{Establishment of occupation chronicles in Grotte Mandrin using sooted concretions: Rethinking the Middle to Upper Paleolithic transition}

\author{
Ségolène Vandevelde ${ }^{a,}{ }^{*}$, Jacques Élie Brochier ${ }^{b}$, Christophe Petit $^{\mathrm{a}}$, Ludovic Slimak ${ }^{\mathrm{c}}$ \\ a Université Paris 1 - Panthéon-Sorbonne, UMR 7041, ArScAn Équipe Archéologies environnementales, Maison Archéologie \& Ethnologie (MAE), \\ René-Ginouvès, 21, allée de l'Université, 92023 Paris, Nanterre Cedex, France \\ ${ }^{\mathrm{b}}$ Aix Marseille Univ, UMR 7269, LAMPEA, Maison méditerranéenne des sciences de l'homme, 5, rue du Château de l'Horloge, B.P. 647, \\ 13094 Aix-en-Provence Cedex 2, France \\ ' Université Toulouse - Jean Jaurès, UMR 5608, Laboratoire TRACES, Maison de la Recherche Bât 26, 5, allée Antonio Machado, 31058 Toulouse Cedex, \\ France
}

\section{A R T I C L E I N F O}

\section{Article history:}

Received 18 April 2016

Accepted 22 July 2017

\section{Keywords:}

Micro-chronology

Parietal carbonated crust

Soot deposit

Middle/Upper Paleolithic transition

Grotte Mandrin

\begin{abstract}
A B S T R A C T
Soot marks, witnesses of past human activities, can sometimes be noticed in concretions (speleothem, travertine, carbonated crust, etc.) formed in cavities. We demonstrate here that these deposits, generally ignored in archaeological studies, turned out to be a perfectly suitable material for micro-chronological study of hominin activities in a site. At the Grotte Mandrin (Mediterranean France), thousands of clastic fragments from the rock walls were found in every archaeological level of the shelter. Calcareous crusts containing soot deposits are recorded on some of their surfaces. They appear in thin section as thin black laminae. Microscopic observation of these crusts revealed that they kept track of many occupations. We show that is possible to link them with the archaeological units identified during the excavation. Minimum Number of Occupations (MNO) can be built out of these sooted crusts. MNO are usually high and attest to the cumulative nature of each archaeological unit. They are witnesses of each occupation of hominin groups in each archaeological level of the cave. This study also shows that, in Grotte Mandrin, a very short time separates the first Middle/Upper Paleolithic transitional groups' occupations from those of the last Mousterians. The research perspectives on soot deposits are diversified and raise the possibility of studying multiple aspects of past human life, and in this case, to rethink the Middle/Upper Paleolithic transition, with an unmatched temporal resolution. Sooted concretion analysis provides high temporal resolution archaeology. There is a real possibility of extending this study with chronological implications to cavities of all ages and areas.
\end{abstract}

\section{Introduction}

What would prehistoric archaeology look like if a high temporal resolution could be obtained, just like dendrochronology provides to more recent periods? What if the minimum number of occupations (MNO) in an archaeological unit could be precisely evaluated? What if we could provide evidence of the coexistence of the first Upper Paleolithic groups with the last Mousterians on a regional scale? What would be the global consequences on our conception of the Middle to Upper Paleolithic transition?

\footnotetext{
* Corresponding author.

E-mail address: segolene.vandevelde@univ-paris1.fr (S. Vandevelde).
}

Soot deposits trapped in carbonated concretions (speleothem, parietal crust, travertine, etc.) are the witnesses of human occupation in the cavities, for all areas and all periods. Thus, the analysis of this geological object offers insight into the behavior of past societies. Few studies have investigated such material (see for example Benington et al., 1962; Genty et al., 1997b, 1998; Delannoy et al., 2009) and the issues of the micro-chronology of site occupation (Genty et al., 1997b; Verheyden et al., 2006), and the link between archaeological deposits and speleothems (Petránek and Pouba, 1951; Gradzióski et al., 2001; Gradziński et al., 2007; Martínez-Pillado et al., 2010, 2014), though sometimes discussed, are never considered together. Previous investigations have suggested that soot deposits are a very good marker of human presence (Gradzióski et al., 2001; Gradziński et al., 2003; Martínez-Pillado 
et al., 2010, 2014) and may be directly dated to identify periods of attendance at a site (Petránek and Pouba, 1951; Benington et al., 1962; Gradzióski et al., 2001; Gradziński et al., 2003, 2007), though none have investigated the utility of these markers as a tool for micro-chronological studies of site occupation and linked the occupation sequences reconstructed with the associated archaeological level.

The study conducted at the Balma de la Margineda (Andorra) is the first to have made the connection between soot deposits in concretions found in several levels of a rock-shelter, the chronicle of site occupations, and the archaeological layers associated with the occupations. In this case, the formation of parietal carbonated crusts trapping more than 30 soot films proved to be contemporary with a single archaeological Azilian layer, showing its cumulative nature. The position of soot films, always the same within repeating annual doublets, points to seasonality of occupation of the Azilian hunters during the Capra ibex mating season (Brochier, 1997, 1999, 2002, 2007, 2008).

The present research was conducted at the Grotte Mandrin (Drôme, Mediterranean France). In 2006, L. Slimak, the archaeologist in charge of research, identified apparent soot deposits on a quantity of clastic fragments coming from every archaeological level of the rock shelter. During the last 10 years, these fragments have been systematically sampled during each annual field season in every layer of the rock shelter. The present study focuses on series of these samples from which we obtained the MNO. We obtained an unexpectedly high temporal resolution, having profound implications for the questions about the transition from Middle to Upper Paleolithic. Indeed, we were able to reconstruct level-by-level micro-chronological chronicles of human site occupation in connection with the formation of archaeological deposits. This raises the possibility of investigating the micro-chronology of the Middle to Upper Paleolithic transition, by addressing the question of whether long (millennium, century) or short (years, seasons) periods of time separated Mousterian from Neronian or from Protoaurignacian occupations in Mediterranean France.

The goal of this paper is to demonstrate how and why parietal soot traces trapped in concretions offer a micro-chronological tool to understand human occupation of caves and rock shelters. We describe first the material studied (sooted concretions), then the method developed to analyze it, and finally the archaeological results obtained on the Middle to Upper Paleolithic transition at the Grotte Mandrin. Grotte Mandrin preserves roughly the last $10 \mathrm{ky}$ of the Middle Paleolithic and records all the cultural phases of the end of the Middle Paleolithic, as well as the first appearance of the Upper Paleolithic in Mediterranean France. It thus represents the most complete sequence from Middle to Upper Paleolithic of the Mediterranean area, from Italy to Spain, in regard to both the cultural phases (Slimak, 2004, 2008) and the chronological framework of the last Neanderthal societies built in Mediterranean France (from 42 to 50-55 ka cal. BP; Higham et al., 2014).

\section{Material and methods}

The Grotte Mandrin is a rock shelter explored since 1990, located in the middle Rhône Valley, on the left bank of the River (Fig. 1). The deposits are divided into 10 stratigraphic units that are further subdivided into 13 archaeological levels (Fig. 2). The lower part of the sequence (layers J to $G$ ) is attributed to classic Mousterian occupations, while the upper part of the sequence documents late Middle Paleolithic occupations (levels F to B2) and Early Upper Paleolithic occupations (level B1). At the very top lays a Neolithic level (layer A), recording multiple human cremation events (Slimak, 2006, 2007, 2008; Higham et al., 2014). Hearth structures and charcoal concentrations have been identified in

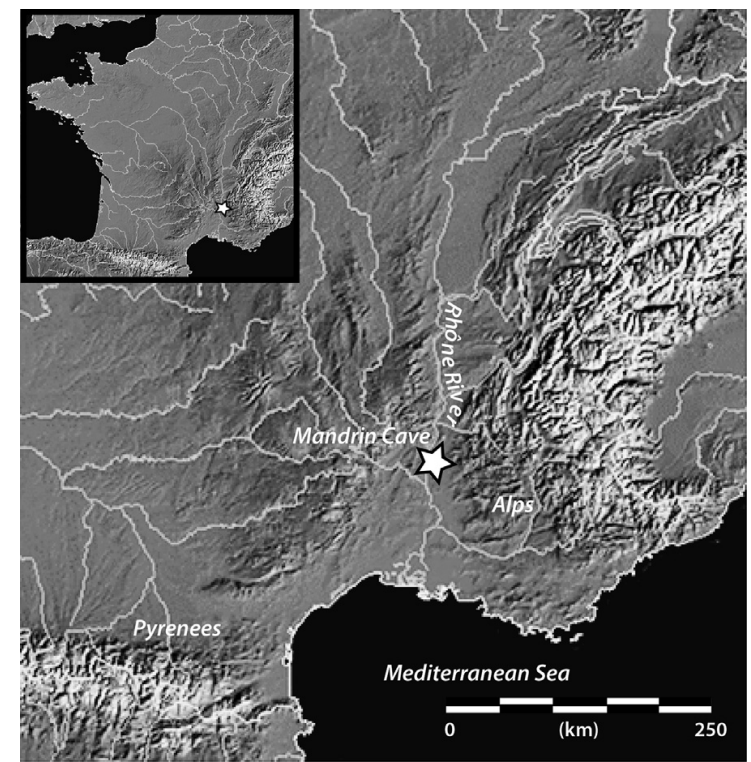

Figure 1. Location of the Grotte Mandrin (Drôme, France). The rock shelter is opened to the North, facing the Mistral wind. It is located in the middle Rhône Valley, on the left bank of the River.

levels E, D, C, B, and A. In levels E, C, and at the base of layer B (level $B 3)$, principal hearth structures have been recognized in the same location in the exact middle of the opening of the porch. This repetitive use of the same location is probably for ventilating smoke. Cremation events in layer A were mainly localized under the vault of the rock shelter. Note that layers $\mathrm{F}$ through $\mathrm{J}$ have only been excavated in two test-pits, SD91 and SD98 (Fig. 2), and F is only partially excavated in the central zone. This probably explains why there are no formally identified hearth structures for these units. Nevertheless, burned elements (flint, bone, wood) can be found in every layer.

\subsection{Material studied: laminated carbonated crusts trapping black films}

We examined soot deposits cemented into parietal carbonated crusts that were recovered from clastic fragments from the crumbling of the rock shelter walls. The clastic fragments were systematically collected in the various sedimentary units of the rockshelter's stratigraphy throughout the entire site.

The size of the clastic fragments ranges between 1 and $25 \mathrm{~cm}$, with a majority between 3 and $8 \mathrm{~cm}$. These limestone clasts are in the form of platelets that have flaked off the cave wall. Most of the time, one side is smooth and covered by the parietal carbonated crust, while the other side is a fresh fracture from the rock of the cave wall. Both sides can be smooth where carbonate deposition occurred inside the crack separating the clast from the wall before it completely separated and fell. The parietal carbonated crust may have a flat or a budding structure. When the crust is flat, the external appearance of the clast is smooth. When the crust is budding, the external appearance of the clast is very rough, with a stromatolitic structure. When both sides are encrusted, the crust may be thicker on one side rather than on the other. The different sides may also bear either type of crusting. Sometimes postpositional events may be visible with, for example, a sparitic crust, formed on the ground, covering the parietal crust (Supplementary Online Material [SOM] Fig. S10a). Dissolution of a few micrometers of the external part of the parietal crust can also sometimes be seen in thin sections (SOM Fig. S10g, h). 


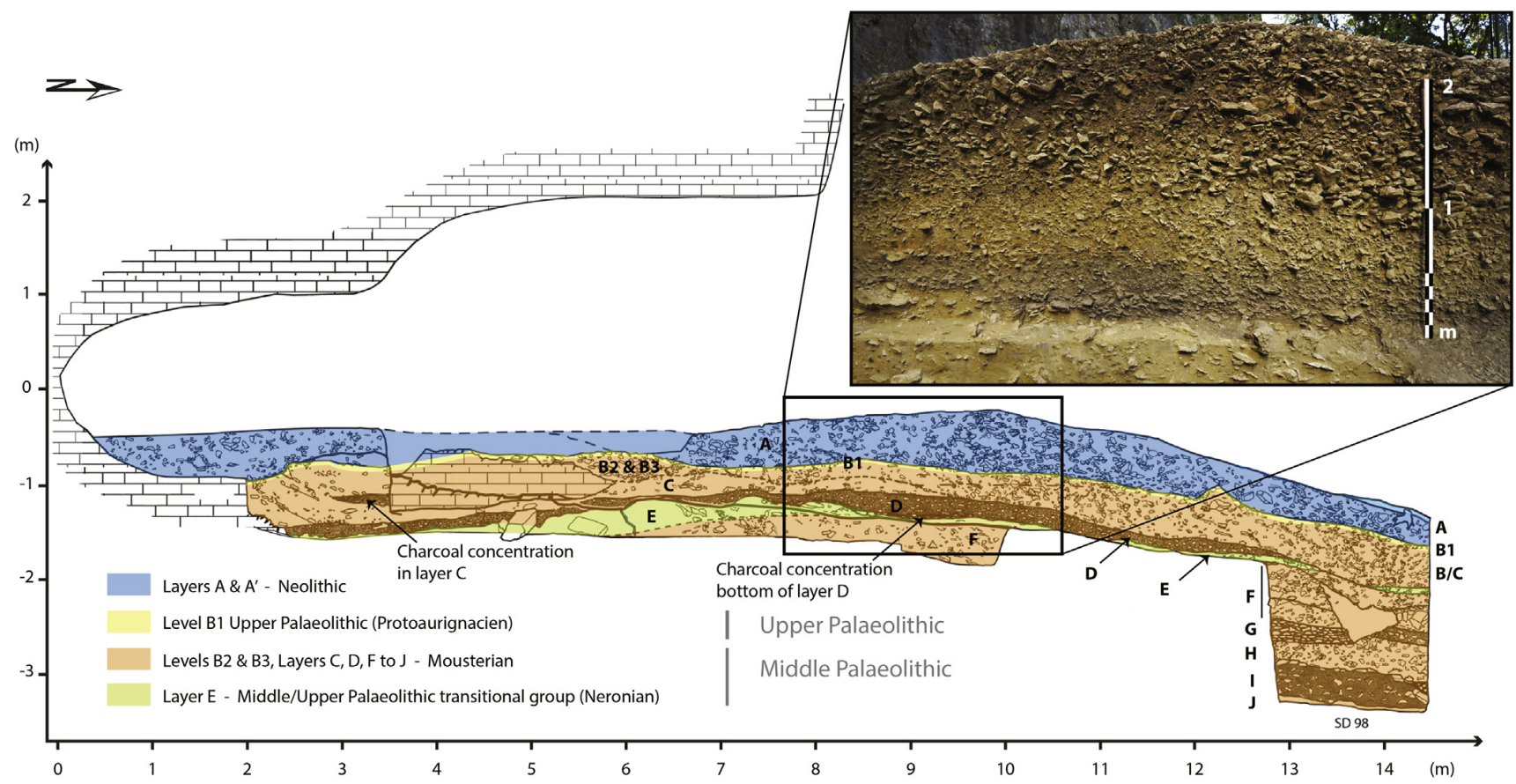

Figure 2. Grotte Mandrin stratigraphy. The focus is on the upper part of the stratigraphy (F to B1, $52-42$ ky cal. BP), with the two critical periods of replacement of the Mousterian groups by other culturally different groups. Definition of each material culture is based on lithic technologies. Note that the square is a close-up of the upper part of the stratigraphy, with layers A, B, C, D, E, and F. The studied clasts bearing sooted concretions were systematically collected upon sight in all the excavated areas, since the 2006 excavation campaign, without focusing on or excluding any particular study area.

The same type of crust is still precipitating in the rock shelter. The crusting takes place throughout the shelter, on the vault and the walls. In some places, the wall is "fresh" because of the recent fall of an encrusted clast. The presence of epilithic and endolithic microorganisms (for example: fungi, lichens, algae) on the walls and vault can color the rock gray or green in some areas. Some of the concretions can also look pinkish due to iron oxides. Unlike the green organic formations, black soot deposits resulting from combustion events are preserved in the carbonates. Experimentation shows that when a fire is made, the soot is covered in a few months by a thin veil of carbonates.

Microscopic observation of the archaeological samples shows that what might appear as a single black lamina at low magnification usually resolves into numerous black films a few micrometers thick (Fig. 3). The black deposits are identified as soot and cannot be confused with metallic oxides (Cf. SEM image, EDS spectrum, Raman spectrum, and detailed explanations in SOM Fig. S3-6).

The carbonated crusts trapping soot are present on clasts found throughout the stratigraphy in the various sedimentary units of the site. These concretions generally have a budding stromatolitic structure showing their biochemical genesis (Fig. 4). The formation of the concretions depends on rainfall, and more particularly moisture, which affect the activity of algae, lichens, and bacteria living on the cave wall. Bio-mineralization is induced when the organic activity modifies the physicochemical conditions of the environment in a way that favors the precipitation of minerals. The growth of concretions is a chemical process of dissolution and precipitation of carbonates, and microorganisms can take part in this process by the absorption of $\mathrm{CO}_{2}$. Cyanobacteria, fungi, and bacteria all contribute to the precipitation of carbonates. Their involvement in carbonate crystallogenesis of the Grotte Mandrin's parietal crusts is attested by direct actualistic observation, by the presence of mycelial hyphae on some of the archaeological samples indicating organic activity on the walls and vault of the rock shelter in the past (SOM Fig. S10b), and by the budding structure of the crust that is similar to the parietal stromatolites observed in the Balma de la Margineda, where Brochier (2008) notes the major role played by endolithic living organisms in the genesis of concretions.

The formation process of these sooted carbonated crusts is simple and follows a repeating cycle (Fig. 5) whereby calcium carbonates, mainly calcite, precipitate on the walls and vault in the form of flat or budding laminae, humans occupy the cave and make fire that deposits soot on the walls and vault, and the soot layer is then trapped by further deposition of carbonate. In other words, the smoke is deposited on the vault and walls of caves and rock shelters as soot films, which are preserved in the carbonated crusts under favorable circumstances. This means that each soot deposit has to be covered by a carbonate veil quickly enough to be preserved. The result is the formation, on the walls and vault of the cavity, of a crust in the form of a "layer cake" with soot films within the calcite laminae. The next stage is the flaking of the encrusted walls and vault of the rock shelter, producing encrusted limestone chips that are later recovered in the various sedimentary units during the excavation. Because peeling does not occur everywhere at the same pace, each clast would bear a specific sooted coat recording a specific sequence of soot films. The length of these individual sequences varies.

The parietal carbonated crusts of Mandrin cave are laminated. The kind of lamination depends on seasonal hydrological variations, which lead to the formation of growth laminae, with alternating micritic (WPL = white porous laminae) and micro-sparitic $(\mathrm{DCL}=$ dark compact laminae) laminae. These are generally annual for speleothems (Genty et al., 1995, 1997a; Baker et al., 2008) and can be easily observed on thin sections with transmitted light. In concretions with annual lamination, the positions of soot films within DCL/WPL doublets can also give information about season of occupation of the site, and thus about the dynamics 


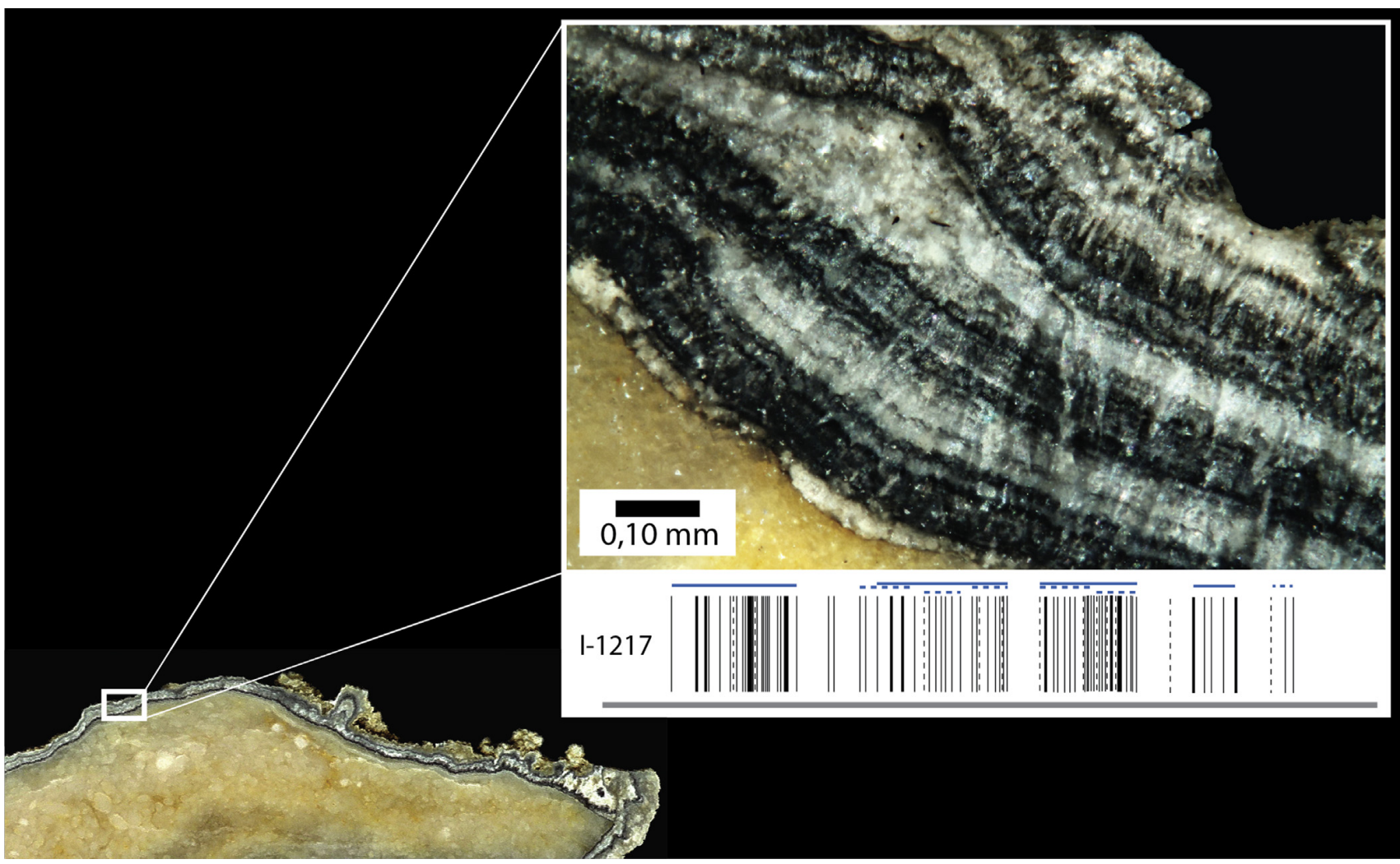

Figure 3. Microscopic observation of what might appear as a single black lamina at low magnification shows a multitude of black films a few micrometers thick. These soot deposits are traces of many recurrent human occupations in the rock shelter. In the barcode diagram, a full line corresponds to a soot film and a dashed line indicates an uncertain soot film. Polished section, $\times 100$, RL.

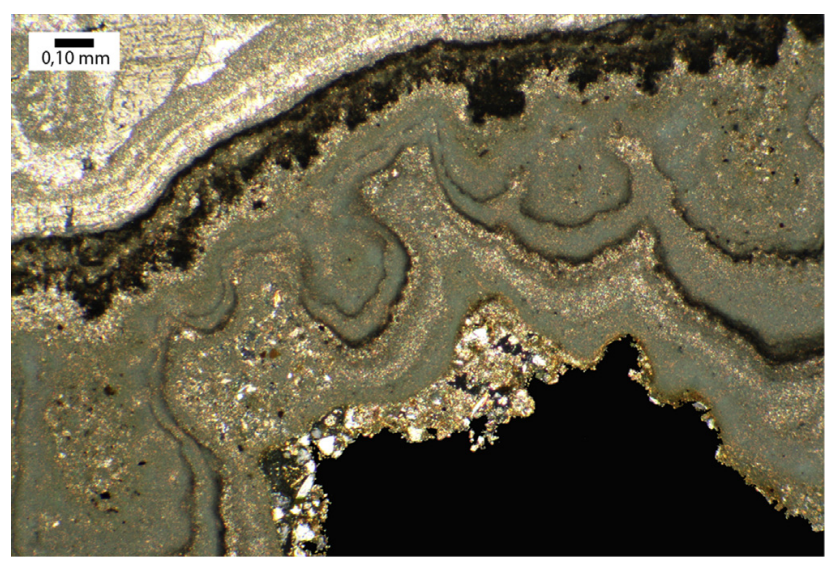

Figure 4. Budding stromatolitic structure of a parietal sooted crust (layer C). Soot is preferentially trapped at the top of the buds. Note the bioclastic limestone chip under the coating and the sandy residues from the sedimentary unit, in which the clast was buried. The parietal stromatolitic crust is here presented in its growing position on the rock vault (downward). Thin section, $\times 50$, combination of XPL + RL enhances the discrimination of micrite and sparite.

of occupation of the cavity by past societies. It is important to note that the annual nature of DCL/WPL doublets identified in the parietal carbonated crust of the Grotte Mandrin, though consistent with the common annual formation of such doublets in speleothems, is not proven yet. However, it is clear that the chronological resolution is not secular, and in the worst case is decennial. Therefore, our analysis is based on the assumption that Grotte
Mandrin's parietal stromatolites have a cyclic lamination with an annual to decennial resolution.

\subsection{Methods}

Because no single clast preserves a continuous temporal record of occupations over the entire stratigraphic record, we employ a barcode method for combining data from different clastic sequences found within the sedimentary units to compile a longterm record of occupations. Each clastic sample records a series of occupations while it was formed on the vault or wall of the cave. Once the clast detaches from the wall and is deposited, soot is no longer trapped and the record of occupation stops. Because clasts detach from the cave walls and vault at different times, the series of clasts obtained from a single stratigraphic unit overlap in the period of time recorded. Once aggregated, they should provide a continuous or nearly continuous record of occupation over the time represented within the stratigraphic unit. To create a continuous record of occupation, the soot deposition sequence needs to be compared and aligned from the various clasts of a stratigraphic sequence. To do this, the series of soot films from each clast are carefully documented from photographs as "barcode" diagrams. The black solid lines represent the soot films and the spaces inbetween represent the carbonate laminae crystallized in the absence of human occupation. In each sedimentary unit, the different samples analyzed allow us to build a continuous sequence of human occupation of the site by simply matching the barcodes from the various clasts taken from a sedimentary unit (Table 1). Finally, the counting of soot films by sedimentary unit provides a MNO specific to each archaeological unit. 


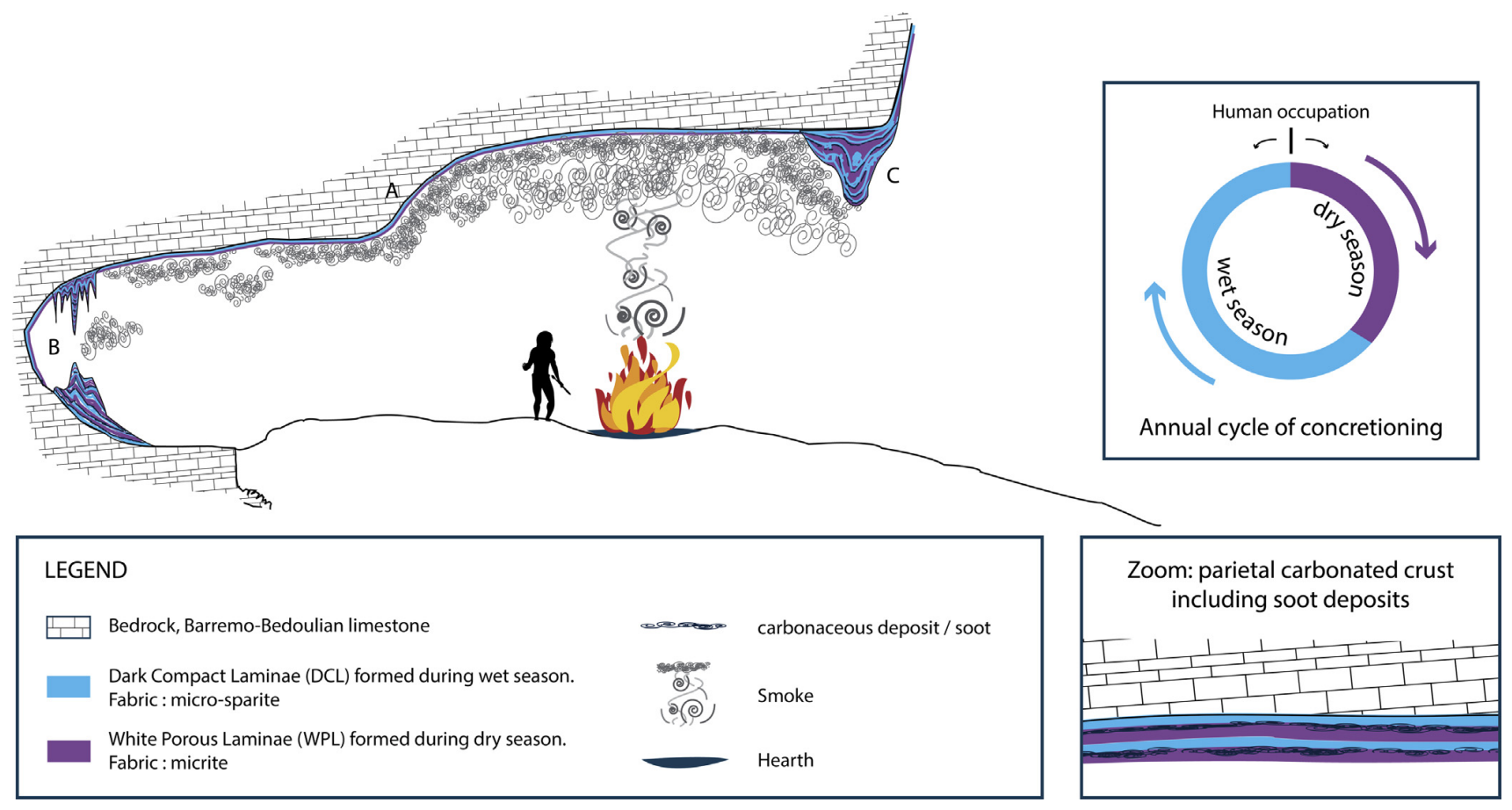

Figure 5. Schematic representation of the process of soot incorporation in laminated concretions. Case A: incorporation in carbonated crust (as in Grotte Mandrin). Case B: incorporation in speleothem. Case C: incorporation in travertine. Figure illustrates general cases. In the case presented, the human occupation is placed between the wet and dry season. This case is just one possibility among others.

Table 1

Synthesis of minimum numbers of occupations (MNO) in each archaeological level of the Grotte Mandrin. ${ }^{a}$

\begin{tabular}{|c|c|c|c|c|c|}
\hline \multirow[t]{2}{*}{ Layer } & \multirow[t]{2}{*}{ Level } & \multirow[t]{2}{*}{ Period } & \multicolumn{2}{|c|}{$\begin{array}{c}\text { Number of sample } \\
\text { studied }\end{array}$} & \multirow[t]{2}{*}{ MNO } \\
\hline & & & $\begin{array}{l}\text { In polished } \\
\text { sections }\end{array}$ & $\begin{array}{l}\text { In thin } \\
\text { sections }\end{array}$ & \\
\hline A & & Neolithic & 10 & & $29(30)$ \\
\hline \multirow[t]{3}{*}{ B } & B1 & Protoaurignacian & 10 & & 6 \\
\hline & B2 & Mousterian (Post-Neronian II) & 10 & & 9 \\
\hline & B3 & Mousterian (Post-Neronian II) & 10 & & 14 \\
\hline \multirow[t]{2}{*}{ C } & $\mathrm{C} 1$ & Mousterian (Post-Neronian II) & 10 & 6 & $38(41)$ \\
\hline & $\mathrm{C} 2$ & Mousterian (Post-Neronian II) & & & \\
\hline D & & Mousterian (Post-Neronian I) & 10 & 2 & $30(34)$ \\
\hline E & & Neronian & 10 & 4 & $18(20)$ \\
\hline $\mathrm{F}$ & & Mousterian (Rhodanian Quina) & 10 & & $21(23)$ \\
\hline G & & Mousterian (Ferrassie) & 10 & & $12(19)$ \\
\hline $\mathrm{H}$ & & Mousterian & 10 & & $8(9)$ \\
\hline I & & Mousterian & 10 & & $70(82)$ \\
\hline $\mathrm{J}$ & & Mousterian & 10 & & $18(26)$ \\
\hline Total & A to $\mathrm{J}$ & & 120 & 12 & $273(313)$ \\
\hline
\end{tabular}

The numbers in brackets take into account the "uncertain soot films" (= dotted lines in barcode diagrams).

These synthetic sequences are combinations of the individual chronicles recorded from several samples in each archaeological level.

Currently, 10 samples containing soot have been studied in polished section for each archaeological level (here C1 and C2 are combined) + some thin sections (12) for layers $\mathrm{C}, \mathrm{D}$, and $\mathrm{E}$.

a MNO in the current state of research. These MNO are calculated from the synthetic sequences.

2.2.1. Sample preparation and analysis The protocol that proved to be the most suitable for preparation, observation, and analysis of sooted calcareous crusts is as follows:

- Polished sections and thin sections of each clast were prepared by cutting and polishing the section of the encrusted limestone chip along the concretions' growth axis.
- Microscopic observation of the polished sections with reflected light and counting of the black films was carried out next. Subsequently, microscopic observation of the thin sections with reflected and/or transmitted light was used to document the number of black films and their position in the WPL/DCL pairs.

- Photographs of the area where the films are the most numerous and most visible were then taken.

- We next took measurements of the distances between the films and mapped the data in the graph style of a "barcode."

- Finally, the barcode diagrams were checked against the films under a microscope.

Polishing is undoubtedly the most delicate step of preparation. Its quality and grain greatly influence the legibility of the films during observation under a microscope. ${ }^{1}$

2.2.2. Extraction and mapping of raw data In order to effectively extract and map the raw data, we borrowed a software from dendrochronology and adapted them to our object of study (module from DataWald platform, G. L. Conception-Lambert, 2014). This procedure allows both a rapid and accurate data collection and the traceability of actions by saving a picture of the transect and of the points locations. The first step is to calibrate the scale of the image. Then, the user points to the soot film directly on the image and assigns a code indicating whether the soot film is certain or uncertain. The distance between the films is automatically calculated and saved in a text file exportable in a spreadsheet. This software offers high measurement accuracy and allows an individual to work on multiple images at once, without

\footnotetext{
${ }^{1}$ It turns out that the most appropriate grain size that can be selected for a polished section observed with reflected light is a $12.8 \mu \mathrm{m}$ grain size $=500$ FEPA or $9.3 \mu \mathrm{m}$ grain size $=600$ FEPA. This choice must be adjusted to the material and technique of polishing (free grains, abrasive discs, etc.). For observation, it may be advisable to varnish the sample surface.
} 
having to attempt to align them. The result is that for one sample that may be spread over several images, data can be extracted along a single transect to construct a barcode diagram. This is a highly effective tool in the context of large-scale data processing. 2.2.3. Matching of barcode diagrams Barcode diagrams are next distended or contracted in order to match them and to build a synthetic sequence of films for each archaeological level. The distension/contraction step is necessary because the calcium carbonates growth rate varies from one place of the vault to another, and therefore from one sample to another. At the same time, all points of the vault and walls are subject to the same changes in meteorological conditions. The carbonate growth rate is thus influenced throughout the cave in a uniform way (acceleration or deceleration), maintaining proportionality between samples, and thus allowing the matching of individual sequences by distension/ contraction of barcode diagrams.

It is important to note that variation in the rhythms of soot films' succession in carbonates creates a unique series of variation in the gaps between soot layers, and thus allows matching between sequences. Matching can therefore be done graphically (Cf. examples of graphical correlations in SOM Fig. S7).

At the Grotte Mandrin, it is usually ${ }^{2}$ impossible to match the individual sequences found on fragments coming from two different archaeological layers by a set of distension/contraction of the diagrams. It is, however, possible to do it with samples from the same layer. This demonstrates two points in retrospect. First, the growth rates of the carbonated crusts, although different in each point of the wall, follow the same trends throughout the cave. Second, that the walls and vault disintegrate quickly enough for the carbonated crusts on limestone chips to be contemporary with the archaeological level in which they fall, but also slowly enough to allow time for the parietal carbonated crusting to form.

2.2.4. Minimum numbers of occupations The MNO derived from the maximum number of films preserved on a single limestone platelet is absolutely certain. Those extrapolated from combinations of individual sequences, and therefore from the synthetic sequences (combination MNO), are theoretically less sure if there are errors in sequence alignment. That said, the graphical correlation of the series is very consistent, and we therefore consider the MNOs derived from the synthetic sequences reliable. Still, taking into account that the uncertain films would increase the MNO, the combination MNO value is indicated by brackets in Table 1 . The term "Minimum" is used for three reasons: first, because it refers to the number of soot films recorded and preserved inside the concretion; second, because two occupations close in time should only leave one deposit on the vault depending on the rate of carbonate accretion; and third, because occupations without fire are possible (although unlikely with a true human occupation including at least one night in the shelter).

\section{Results and discussion: rethinking the Middle/Upper Paleolithic transition}

Over the entire sequence (Table 1), 13 archaeological levels are characterized by a minimum number of 273 (313) occupations, including 244 (283) in Pleistocene levels B1-J. A MNO of 136 (147) is recorded for levels $\mathrm{B} 1$ to $\mathrm{F}$, which embrace the last $10 \mathrm{ky}$ of the

\footnotetext{
${ }^{2}$ No overlap was observed outside of areas of potential overlap (meaning at the start and end of synthetic sequences). That is to say that there is no overlap possible between samples coming from two sedimentary units that are not adjacent. When two sedimentary units are adjacent, samples bearing soot deposits recorded at the beginning of the period corresponding to the upper archaeological level can also have recorded some soot films that formed during the adjacent period corresponding to the lower archaeological level.
}

Middle Paleolithic and the first appearance of the Upper Paleolithic in Mediterranean France.

\subsection{Question of contemporaneity of Mousterian and Neronian occupations-Layers F-E}

Layer $\mathrm{F}$ records one of the best preserved units of a classic Mousterian industry (Slimak, 2004), defined as rhodanian Quina Mousterian (Combier, 1967; Le Tensorer, 1981; Bordes, 1984; Slimak, 1999, 2002). Layer E overlays the rhodanian Quina Mousterian assemblage and is attributed to the Neronian, a Middle to Upper Paleolithic transitional group dated around $50 \mathrm{ky}$ cal. BP (Slimak, 2004; Higham et al., 2014). It was initially perceived as an evolved Mousterian and a parallel culture of the Châtelperronian for the Rhône valley (Combier, 1967, 1990). It has been fully described, defined, and understood primarily based on Mandrin layer E industries (Slimak, 2004). The Neronian assemblage is technically very complex, requiring a systematic selection of high quality raw material coming from a large area including both banks of the Rhône River (Slimak, 2004). Based on the production of standardized microlithic points used as mechanically propelled weapons (Metz, 2015), it shares no technical traits with the underlying rhodanian Quina Mousterian level (layer F). See SOM for a more detailed version.

Layer $\mathrm{E}$ is sedimentarily almost identical to layer $\mathrm{F}$, but with a higher concentration of charcoals of anthropogenic origin. As mentioned above, because of the progressive crumbling of the wall, an encrusted limestone chip recovered in F level potentially may have recorded soot deposits that are contemporaneous with levels $\mathrm{G}$ and $\mathrm{F}$, but of course not with the overlying level $\mathrm{E}$. Thus, it is not surprising that the synthetic sequences of layers $\mathrm{F}$ and $\mathrm{E}$ overlap. Some clasts found in E bear soot deposits recorded during F occupations. Thus, the overlapping part of the layer E synthetic sequence can be attributed to $\mathrm{F}$ (Fig. 6). The thickness of carbonates formed between the two first occupations of the Neronian and between the last rhodanian Quina Mousterian occupation and the first one of the Neronian are equal. In both cases, this corresponds to a very short time (few seasons or few years), meaning that there is no large temporal gap (at a human lifetime scale) between the last occupations of the Mousterian group (layer F) and the first of the Neronian (layer E). In other words, two distinctive groups succeeded each other in the site within less than a single human lifetime.

\subsection{Question of contemporaneity of Mousterian and \\ Protoaurignacian's occupations-From layer C to level B1}

Layer $B$ is a sedimentary unit that records three archaeological levels: levels B3, B2, and B1. The first (B3) is separated from the second (B2) by a thin sterile layer. The third (B1), located at the top of the sedimentary layer, lies directly above level B2 and in some places is in direct spatial contact with the upper part of level B2. In the latter configuration, the distinction between level B1 and B2 is mostly based on technological differences. The two first assemblages (B3 and B2) are assigned to the post-Neronian II, a late Mousterian tradition (Slimak, 2004, 2007). B1 is attributed to Protoaurignacian, which has been traditionally associated with a Homo sapiens population (Benazzi et al., 2015), and has been dated to around 42,000 years cal. BP (Higham et al., 2014).

The Grotte Mandrin is the only site documenting the existence of post-Neronian Mousterian occupations. Indeed, in the other main late Mousterian sequences of the Rhône valley, the last layer preserves the Neronian industry (Mousterian sequences of Moula, Figuier, Maras, Néron-Slimak, 2004, 2007). In the Grotte Mandrin, the post-Neronian phase can be subdivided into two distinct, 


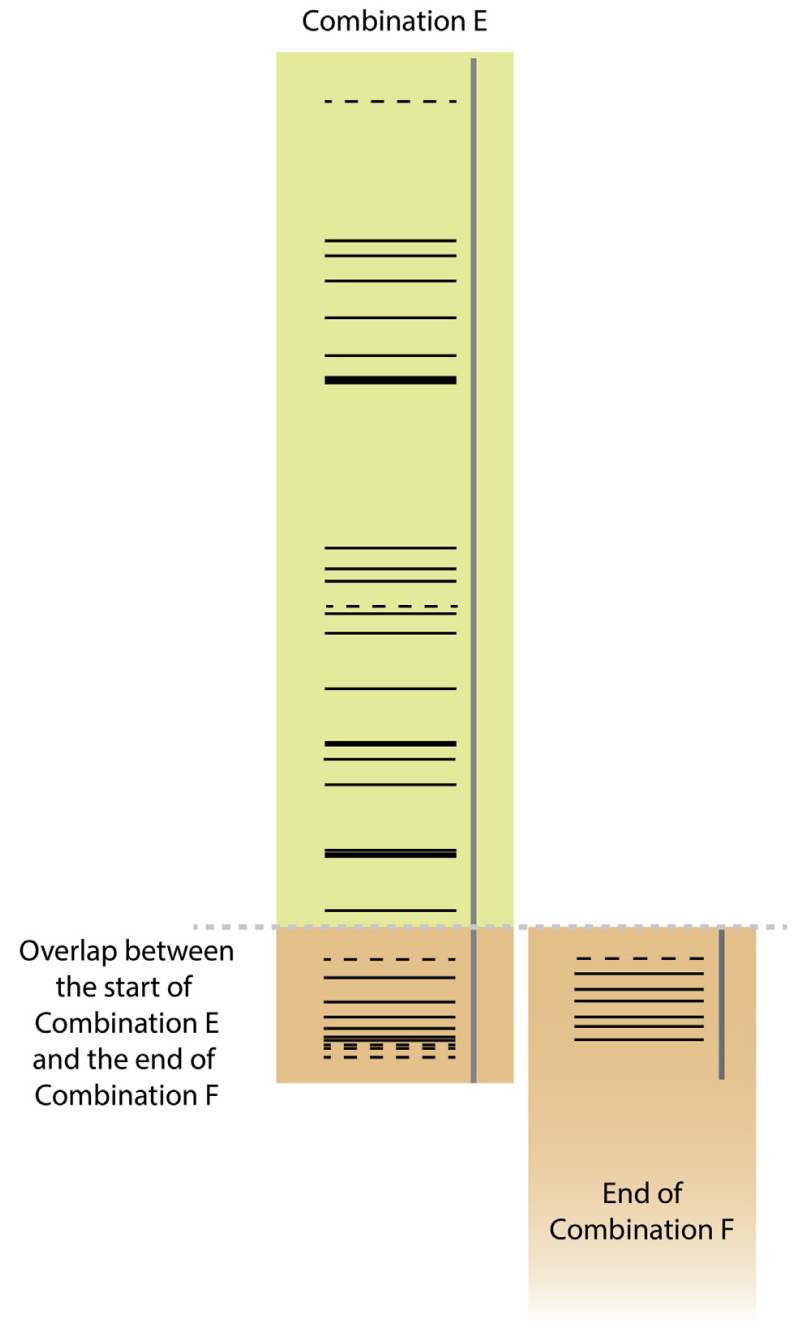

Figure 6. Overlapping of synthetic sequences of layers $\mathrm{F}$ and $\mathrm{E}$. Soot films in the part of the $\mathrm{E}$ sequence overlapped by the end of the $\mathrm{F}$ sequence are attributed to $\mathrm{F}$. E can bear soot films that were deposited during the F period because of the progressive crumbling of walls and vault, but $\mathrm{E}$ occupations cannot be recorded in $\mathrm{F}$ sequence because the clasts have already fallen before the layer E (Neronian) occupations.

technically well differentiated sets: the post-Neronian I (layer D) and the post-Neronian II (layer C and levels B3 and B2). The postNeronian II assemblages are clearly distinguished from both the Neronian and the post-Neronian I. They show a discontinuity with the technical systems of the Neronian, expressed in lithic technical systems, territories, and raw material choices (Slimak, 2004, 2007). The post-Neronian II occupations can be considered as the last expression of the Mousterian in Mediterranean France (Slimak, 2008; Higham et al., 2014), and they precede the presence of the first Protoaurignacian assemblages.

Concerning the Protoaurignacian lithic production at the Grotte Mandrin (level B1), the procurement of siliceous rocks in the Protoaurignacian is mainly local, comparable with that of the postNeronian II. This illustrates the exploitation of a limited territory around the rock shelter by comparison with the Neronian. However, in contrast with post-Neronian II, Protoaurignacian toolmakers were hyper-selective in their raw material choices, using only the best quality local flint-nodules. The Protoaurignacian raw material selection is highly systematic and closely aligned to their technological ends, just like in the Neronian (Slimak et al., 2006). See SOM for a more detailed version.
When studied separately, the limestone chips bearing sooted parietal carbonated crusts coming from the three archaeological levels of layer B allow the construction of three synthetic sequences, with a MNO of 17 for B1, 20 (23) for B2, and 17 (24) for B3. But, just as with the preceding case of the Mousterian-Neronian transition, the synthetic sequences overlap (Fig. 7). Some samples found in the B1 level carry soot films attributable to B1 and B2 and samples found in the B2 level carry films attributable to B3. ${ }^{3}$ This demonstrates that there is no sedimentary hiatus between these levels and that occupations succeed one another in a very short time-lapse (probably from a few seasons to a few years). Thanks to the micro-chronological study of soot films, and thus the high chronological resolution obtained here, it is obvious that there is no large gap in the attendance of the Grotte Mandrin between the last Middle Paleolithic (B2) and the first Upper Paleolithic (B1) levels (Fig. 7). The two groups followed one another in the same place in a very short time, ranging from as short as a few seasons to at most a few years, and certainly within a single lifetime.

Another observation is the overlap of the synthetic sequence of the layer $B$ with the end of the layer $C$ sequence. The four archaeological levels therefore succeed one another quickly, without an occupational hiatus and without a large temporal gap. From layer $\mathrm{C}$ to B1, the site is effectively continuously occupied, although sterile sediments separate levels C, B3, and B2, and even though the sedimentary facies drastically change in texture and color between C and B3. The thin sterile levels between C, B3, and B2 do not, therefore, equate to different occupation phases separated by periods of human absence in the shelter. The sterile levels only show that three episodes of occupation can be archaeologically distinguished. Sedimentary processes in caves and rock shelters are often due to exceptional and rare events. The observed geological or archaeological segmentation, therefore, does not necessarily involve any precise timeline. Our micro-chronological results provide much more refined and precise data concerning the sequence of occupations in the cavity.

To summarize, we are able to analyze two critical moments of the Middle to Upper Paleolithic transition in Mediterranean France. One concerns the time-lapse inbetween the Quina Mousterian assemblage (level F) and the Neronian transitional industry (level E). The other concerns the time separating the very last Mousterian (level B2) and the very first Upper Paleolithic (level B1). It is noteworthy that both Neronian and Protoaurignacian groups succeeded very quickly, or even abruptly, to local Mousterian groups. This short interval almost certainly falls within a single individual's lifespan. The implication is that these different cultures were contemporary, at a human scale, and occurred in roughly the same region.

Our micro-chronological results do not contradict currently known radiocarbon dates (Higham et al., 2014:Supplementary information, Tables S12 and S13). The Bayesian modeling of the time elapsed between archaeological units B2-B3 and C, as well as the duration of B3-B2 occupations, does not exclude the possibility of decennial lengths (see SOM for more information).

It is notable that roughly $10 \mathrm{ky}$ have passed from level E to B1 and that occupations from layer $\mathrm{F}$ to $\mathrm{E}$, and then from $\mathrm{C}$ to $\mathrm{B} 1$, succeed each other quickly. This suggests that the site was unoccupied for thousands of years between layers $\mathrm{E}$ and $\mathrm{D}$ and/or between layers D and C. This underscores the discontinuity of sedimentation in caves and rock shelters in particular and in continental environments in general (excluding lakes). This also suggests that during $\sim 10 \mathrm{ky}$, the shelter was usually unoccupied, with the few exceptions demonstrated here.

\footnotetext{
${ }^{3}$ Of course, MNO must be calculated for each level after matching of these synthetic sequences (Table 1, Fig. 7).
} 


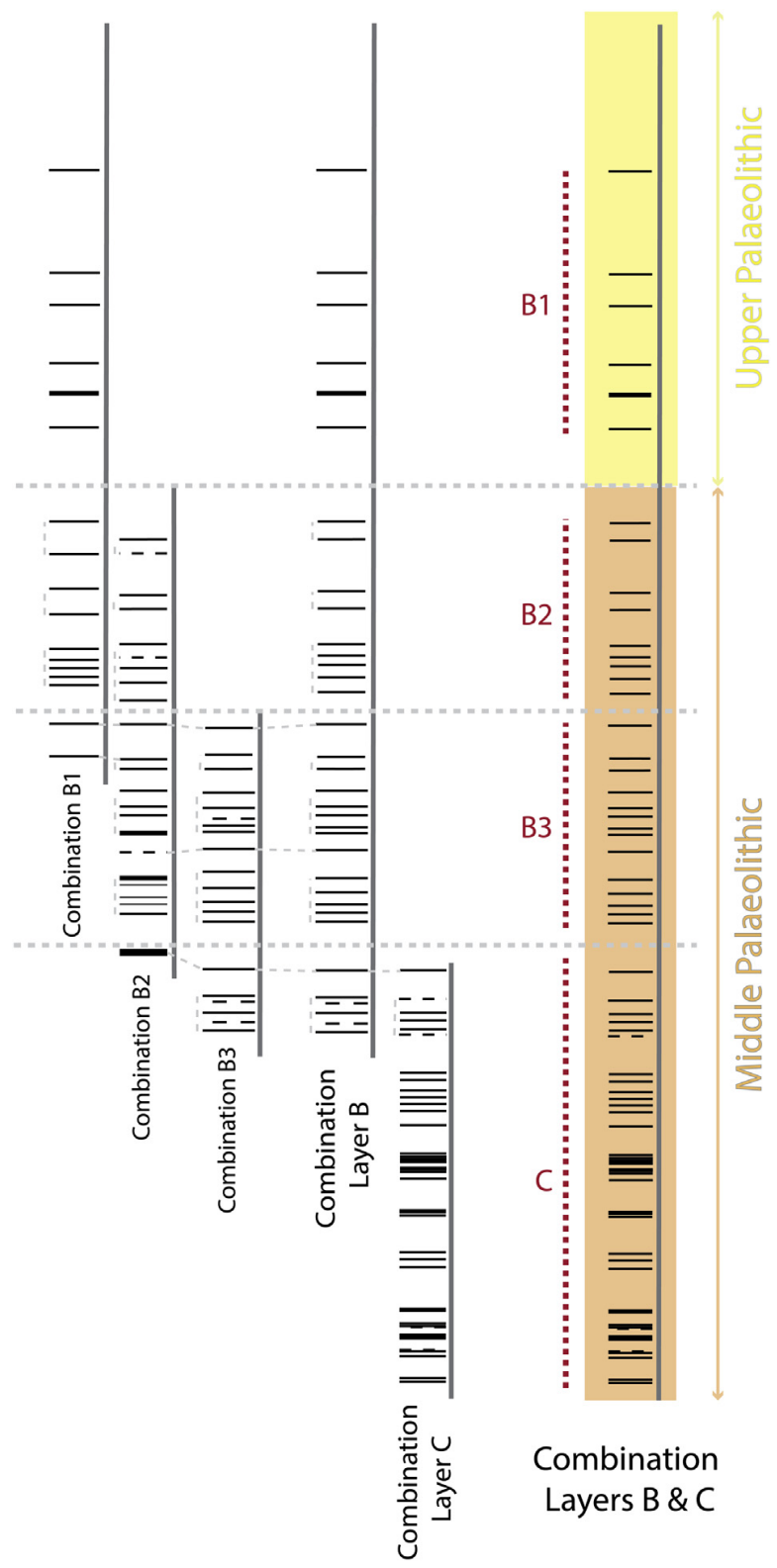

Figure 7. Overlapping of synthetic sequences of levels B1, B2, and B3, and of layers B and C. The combined MNOs of different sets are as follows: 6 in B1, 9 in B2, and 14 in B3, for a total of at least 29 occupations in layer B and 38 (41) occupations in C. There is a MNO of 61 (64) for the post-Neronian II Mousterian phase (levels C to B2) and a MNO of 6 for the Protoaurignacian phase.

\section{Conclusions and perspectives}

The micro-chronological approach used here potentially has applications for a wide variety of questions from different fields, including, for example, the domestication of fire, mobility studies, pastoralism, etc., with an unmatched temporal resolution.

The basis of micro-chronological study on sooted concretions has been laid and the first results have been obtained at Grotte Mandrin. This study provides unique data on the MNO in each archaeological unit of the cavity. The analysis shows the cumulative nature of the archaeological formations and that, at the human scale, a very short time separates the occupations of the Protoaurignacian from those of the last Mousterians, and that there is also no large gap between the occupations of the Neronian transitional group and those of the
Rhodanian Quina Mousterian preceding them. This is a surprising result, as it suggests that these otherwise culturally distinct groups occupied the same territory at the exact same moment in time. It is also noteworthy in this context that no intercalation of groups can be documented (that is, for example, there are no Quina technologies present in the Neronian layer). This suggests that even if these groups were strictly locally contemporaneous in the region of Grotte Mandrin, the presence of one group excluded the presence of the other from at least the site of Grotte Mandrin. This demonstrates that when the Neronian group occupied this territory, coming back at least 18 different times in the cave, the Quina group never returned. The exact same phenomenon seems to occur at the very end of the Middle Paleolithic. The presence of the Protoaurignacian definitively excluded the local Mousterian group that used to return successively, at least 61 (64) times in the Grotte Mandrin (Fig. 6), exploiting the resources of its surrounding territory (distinguishable by local raw materials from 20 to $30 \mathrm{~km}$ around the rock shelter). This implies that in this part of Eurasia and at the end of the Middle Paleolithic, both Neanderthal and $H$. sapiens were contemporaneous in the same region. Moreover, these data make clear that the Protoaurignacian populations excluded Mousterian populations from their territory. This observation has serious implications for the relations between these hominin groups that can be inferred in Western Europe at the moment of the disappearance of the Neanderthals.

The Rhône Valley corridor has always been, and is still today, a north-south migratory corridor of major importance in Western Europe. It connects the Mediterranean area to northern Europe. Indeed, its status as a migration route probably helps explain why sites along the Rhône contain the oldest Protoaurignacian in Eurasia, the oldest Middle to Upper Paleolithic transition industry in Europe (Higham et al., 2014), and the oldest painted cave in the world (Clottes et al., 1995; Valladas et al., 2004; Delannoy et al., 2012; Sadier et al., 2012). The Grotte Mandrin is therefore a strategic site to explore questions of the succession of human groups, the contemporaneity of culturally and/or biologically different groups, the dynamics of group replacement, and changes in mobility (numerous occupations or not) through the use of the powerful micro-chronological tool presented here.

More generally, the method developed here is based on soot deposits trapped in concretions that are witnesses of human occupations in caves and rock shelters. Note that in rare cases, soot deposits can sometimes also testify to wild fires (Lauritzen et al., 1990; Desmarchelier et al., 2004). Concerning very old concretions containing soot deposits, one can obtain not only evidence of use of fire by the presence of soot and possibly of charcoals inside the concretion (ex. in SOM Fig. S10c), but also possible evidence of the control and "domestication" of fire, insofar as anthropogenic fires can be differentiated from wild fire traces. In all cases, a MNO in the cavity concerned may be established. In many cases, chronicles of cave occupation can also be traced. When soot is recorded in annually laminated concretions such as speleothems, the seasons (wet or dry) of each one of the occupations can be determined. In these contexts of annual temporal resolution, it may be possible to evaluate an average number of occupations in a year, a decade, or a century, and to define the full extent of the period of occupation.

\section{Acknowledgments}

We would like to thank Adelphine Bonneau for carrying out complementary analyses presented in the supplementary online material and Benjamin Lambert (G. L. Conception) for the adaptation of DATAWALD Software (LnSeq module) to our material. Longterm research in Grotte Mandrin has been made possible due to 
two decades of financial support of the French Service Régional de l'Archéologie (SRA) of the Rhône-Alpes region.

\section{Appendix A. Supplementary Online Material}

Supplementary online material related to this article can be found at http://dx.doi.org/10.1016/j.jhevol.2017.07.016.

\section{References}

Baker, A., Smith, C.L., Jex, C., Fairchild, I.J., Genty, D., Fuller, L., 2008. Annually laminated speleothems: a review. Intl. J. Speleol. 37, 193-206.

Benazzi, S., Slon, V., Talamo, S., Negrino, F., Peresani, M., Bailey, S.E., Sawyer, S. Panetta, D., Vicino, G., Starnini, E., Mannino, M.A., Salvadori, P.A., Meyer, M., Pääbo, S., Hublin, J.-J., 2015. The makers of the Protoaurignacian and implications for Neandertal extinction. Science 348, 793-796.

Benington, F., Melton, C., Watson, P.J., 1962. Carbon Dating Prehistoric Soot from Salts Cave. Ky. Am. Antiq. 28, 238-241.

Bordes, F., 1984. Leçons sur le Paléolithique. Tome 2: le Paléolithique en Europe. Editions du CNRS, Paris.

Brochier, J.É., 1997. Couches archéologiques ou "sols d'habitat"? Quelques observations micro-chronologiques dans un abri-sous-roche pyrénéen. Internationa Workshop on Archaeological Soil Micromorphology, Basel.

Brochier, J.É., 1999. Couche archéologique, sol archéologique et distributions spatiales: quelques réflexions (géo)archéologiques sur un vieux problème. Geoarqueol. Quaternar. Litoral Meml. M.P. Fumanal 91-95.

Brochier, J.É., 2002. Les sédiments anthropiques: Méthodes d'étude et perspectives, In: Miskovsky, J.-C. (Ed.), Géologie de la préhistoire: méthodes, techniques, applications, Géopré ed. Presses Universitaires de Perpignan, Paris, pp. 453-477.

Brochier, J.É., 2007. De la sédimentologie à la géoarchéologie. Un demi-siècle de recherches francaises dans les entrées de grottes et les abris-sous-roche. In: Évin, J. (Ed.), XXVIe congrès préhistorique de France. Congrès du centenaire: Un siècle de construction du discours scientifique en Préhistoire. Soc. Prehist. Fr., Avignon, pp. 31-46.

Brochier, J.É., 2008. Estudi geoarqueològic dels dipòsits tardiglacials de la Balma de la Margineda (Capes de la 6 a la 11). In: Guilaine, J., Martzluff, M. (Eds.), Les excavacions a la Balma de la Margineda (1979-1991). Minister d'Afers socials Cultura, Andorra, pp. 34-52.

Clottes, J., Chauvet, J.-M., Brunel-Deschamps, E., Hillaire, C., Daugas, J.-P., Arnold, M. Cachier, H., Evin, J., Fortin, P., Oberlin, C., 1995. Les peintures paléolithiques de la Grotte Chauvet-Pont d'Arc, à Vallon-Pont-d'Arc (Ardèche, France): datations directes et indirectes par la méthode du radiocarbone. C.R. Acad. Sci. Ser. 2. Sci. Terre Planètes 320, 1133-1140.

Combier, J., 1967. Le Paléolithique de l'Ardèche dans son cadre paléoclimatique. Imprimeries Delmas, Bordeaux.

Combier, J., 1990. De la fin du Moustérien au Paléolithique supérieur. Les données de la région rhodanienne. In: Faricy, C. (Ed.), Colloque international de Nemours: Paléolithique moyen récent et paléolithique supérieur ancien en Europe. Mémoires du Musée de Préhistoire d'Ile de France, pp. 267-277. Nemours, 9-11 mai 1988.

Delannoy, J.-J., Gauchon, C., Hobléa, F., Jaillet, S., Maire, R., Perrette, Y., Perroux, A.-S. Ployon, E., Vanara, N., 2009. Karst: from palaeogeographic archives to envi ronmental indicators. Geomorphol. Relief Process. Environ. 2, 83-94.

Delannoy, J-J., Geneste, J-M., David, B., Katherine, M., Gunn, R., Whear, R.1., 2012. Apports de la géomorphologie dans l'aménagement et la construction sociale de sites préhistoriques. Exemples de la grotte Chauvet-Pont-d'Arc (France) et de Nawarla Gabarnmang (Australie). Paléo 23, 85-104.

Desmarchelier, J., Hellstrom, J., Spate, A., 2004. Constraining relative wildfire frequency in the Australian alps over the past 500,000 years, using U-Th dating of speleothem-encapsulated soot layers, 19. Biennial Conference of the Australiasian Quaternary Association, Cradle Mountain, Tasmania.

Genty, D., Bastin, B., Ek, C., 1995. Nouvel exemple d'alternances de lamines annuelles dans une stalagmite (Grotte de Dinant "la Merveilleuse", Belgique) Speleochronos 6, 3-8.

Genty, D., Baker, A., Barnes, W., 1997a. Comparaison entre les lamines luminescentes et les lamines visibles annuelles de stalagmites. C.R. Acad. Sci. Sci. Terre Planètes 325, 193-200.

Genty, D., Dauphin, Y., Deflandre, G., Quinif, Y., 1997b. Exemples de particules d'origine anthropique piégées dans les lamines de croissance de stalagmites Intérêt pour la reconstitution des environnements humains anciens [Examples of anthropogenic particles trapped into stalagmite growth laminae-Interest for the study of prehistoric human activity]. Quaternary 8, 149-157.
Genty, D., Vokal, B., Obelic, B., Massault, M., 1998. Bomb 14C time history recorded in two modern stalagmites-importance for soil organic matter dynamics and bomb 14C distribution over continents. Earth Planet. Sci. Lett. 160, 795-809.

Gradziński, M., Górny, A., Pazdur, A., Pazdur, M.F., 2003. Origin of black coloure laminae in speleothems from the Kraków-Wieluń Upland, Poland. Boreas 32, $532-542$.

Gradziński, M., Hercman, H., Nowak, M., Bella, P., 2007. Age of Black Coloured Laminae Within Speleothems from Domica Cave and its Significance for Dating of Prehistoric Human Settlement. Geochronometria 28, 39-45.

Gradziòski, M., Hercman, H., Nowicki, T., Bella, P., 2001. Dark Coloured Laminae within Speleothems as an Indicator of the Prehistoric Man Activity: Case Study from Domica Cave (Slovakia), Preliminary Results, pp. 263-267, 13th International Congress of Speleology, 4th Speleological Congress of Latin America and Caribbean, 26th Brazilian Congress of Speleology, Brasilia DF.

Higham, T., Douka, K., Wood, R., Ramsey, C.B., Brock, F., Basell, L., Camps, M., Arrizabalaga, A., Baena, J., Barroso-Ruiz, C., Bergman, C., Boitard, C., Boscato, P. Caparros, M., Conard, N.J., Draily, C., Froment, A., Galvan, B., Gambassini, P., Garcia-Moreno, A., Grimaldi, S., Haesaerts, P., Holt, B. Iriarte-Chiapusso, M.-J. Jelinek, A., Jorda Pardo, J.F., Maillo-Fernandez, J.-M., Marom, A., Maroto, J., Menendez, M., Metz, L., Morin, E., Moroni, A., Negrino, F., Panagopoulou, E. Peresani, M., Pirson, S., de la Rasilla, M., Riel-Salvatore, J., Ronchitelli, A. Santamaria, D., Semal, P., Slimak, L., Soler, J., Soler, N., Villaluenga, A., Pinhasi, R., Jacobi, R., 2014. The timing and spatiotemporal patterning of Neanderthal disappearance. Nature 512, 306-309 and Supplementary information.

Lambert, B., 2014. LnSeq module, DataWald platform. G.L. Conception.

Lauritzen, S.-E., Løvlie, R., Moe, D., Østbye, E., 1990. Paleoclimate deduced from a multidisciplinary study of a half-million-year-old stalagmite from Rana, northern Norway. Quatern. Res. 34, 306-316.

Le Tensorer, J.-M., 1981. Le Paléolithique de l'Agenais. Editions du CNRS, Paris.

Martínez-Pillado, V., Aranburu, A., Yusta, I., Stoll, H., Arsuaga, J.L., 2010. Clima y ocupaciones en la Galeria de Estatuas (Atapuerca, Burgos) en los ultimos 14.000 años: Relatos de una estalagmita. MUNIBE (Antropol.-Arkeol.) 61, 89-102.

Martínez-Pillado, V., Aranburu, A., Arsuaga, J., Ruiz-Zapata, B., Gil-García, M., Stoll, H., Yusta, I., Iriarte, E., Carretero, J., Edwards, R., Cheng, H., 2014. Uppe Pleistocene and Holocene palaeoenvironmental records in Cueva Mayor karst (Atapuerca, Spain) from different proxies: speleothem crystal fabrics, palynology, and archaeology. Intl. J. Speleol. 43, 1-14.

Metz, L., 2015. Néandertal en armes? Des armes, et de l'arc, au tournant du 50ème millénaire en France méditerranéenne. Ph.D. Dissertation, Université d'AixMarseille.

Petránek, J., Pouba, Z., 1951. Pokus o datování vývoje jaskynĕ Domice na základě studia tmavých zon v krápnících a sintru (Dating of the development of the Domica Cave, based on the study of the dark zones in the travertine formations). Sb. Ustred. Ústavu Geol. 18, 245-272.

Sadier, B., Delannoy, J.-J., Benedetti, L., Bourlès, D.L., Jaillet, S., Geneste, J.-M., Lebatard, A.-E., Arnold, M., 2012. Further constraints on the Chauvet cave artwork elaboration. Proc. Natl. Acad. Sci. 109, 8002-8006.

Slimak, L., 1999. Pour une individualisation des Moustériens de type Quina dans le quart sud-est de la France? La Baume Neron (Soyons, Ardeche) et le Champ Grand (Saint-Maurice-sur-Loire, Loire), premières données. Bull. Soc. Prehist. Fr 96, 133-144.

Slimak, L., 2002. La grotte du Figuier (Ardèche, France), considérations critiques face à l'analyse d'un complexe du Moustérien. Bull. Soc. Prehist. Fr. 99, 453-460.

Slimak, L., 2004. Les dernières expressions du Moustérien entre Loire et Rhône Ph.D. Dissertation, Université de Provence.

Slimak, L., 2006. Les dernières expressions du Moustérien entre Loire et Rhône. Bull. Soc. Prehist. Fr. 103, 614-617.

Slimak, L., 2007. Le Néronien et la structure historique du basculement du Paléolithique moyen au Paléolithique supérieur en France méditerranéenne. C. R. Palevol 6, 301-309.

Slimak, L., 2008. The Neronian and the historical structure of cultural shifts from Middle to Upper Palaeolithic in Mediterranean France. J. Archaeol. Sci. 35, 2204-2214.

Slimak, L., Pesesse, D., Giraud, Y., 2006. Reconnaissance d'une installation du Protoaurignacien en vallée du Rhône: implications sur nos connaissances concernant les premiers hommes modernes en France méditerranéenne. C. R. Palevol 5, 909-917.

Valladas, H., Clottes, J., Geneste, J.-M., 2004. Chauvet, la grotte ornée la mieux datée du monde. Pour sci. Doss. Temps Datations 42, 82-87.

Verheyden, S., Baele, J.-M., Keppens, E., Genty, D., Cattani, O., Cheng, H. Lawrence, E., Zhang, H., Van Strijdonck, M., Quinif, Y., 2006. The Proserpine Stalagmite (Han-sur-Lesse Cave, Belgium): preliminary environmental interpretation of the last 1000 years as recorded in a layered speleothem. Geol. Belg. 9, 245-256. 


\title{
Journal of Human Evolution
}

\section{Establishment of occupation chronicles in Grotte Mandrin using sooted concretions: Rethinking the Middle to Upper Paleolithic transition}

\author{
Ségolène Vandevelde ${ }^{\mathrm{a},{ }^{*}}$, Jacques Élie Brochier ${ }^{\mathrm{b}}$, Christophe Petit ${ }^{\mathrm{a}}$, Ludovic Slimak ${ }^{\mathrm{c}}$ \\ ${ }^{2}$ Université Paris 1 - Panthéon-Sorbonne, UMR 7041, ArScAn Équịe Archéologies environnementales, Maison Archéologie \& Ethnologie (MAE), \\ René-Ginouvè, 21, allée de I'Université, 92023 Paris Nanterre Cedex, France \\ ' Aix Marseille Univ, UMR 7269, LAMPEA, Maison méditerranéenne des sciences de l'homme, 5, rue du Chàteau de l'Horloge, B.P. 647, \\ 13094 Afx-en-Provence Cedex 2, France \\ 'Université Toulouse - Jean Jaurès, UMR 5608, Laboratoire TRACES, Maison de la Recherche Bât 26, 5, allée Antonio Machado, 31058 Toulouse Cedex, \\ France
}

\section{Appendix A. Supplementary Online Material (SOM)}

\section{A.1. Search History at the Grotte Mandrin}

In 2006, L. Slimak identified soot deposits on a quantity of clastic fragments coming from every archaeological level of the cavity. He collected them for further study and showed them to the geologist J.-L. Guendon, who put him in contact with J.É. Brochier, following his pioneer work on similar deposits from Balma de la Margineda, described in the text. A preliminary set of samples from several distinct layers (B, C, D, and E) was given to J.É. Brochier for study. In 2013, the collection was enriched with new samples and transferred to $\mathrm{S}$. Vandevelde as part of a Master of Science project, under the supervision of J.É. Brochier.

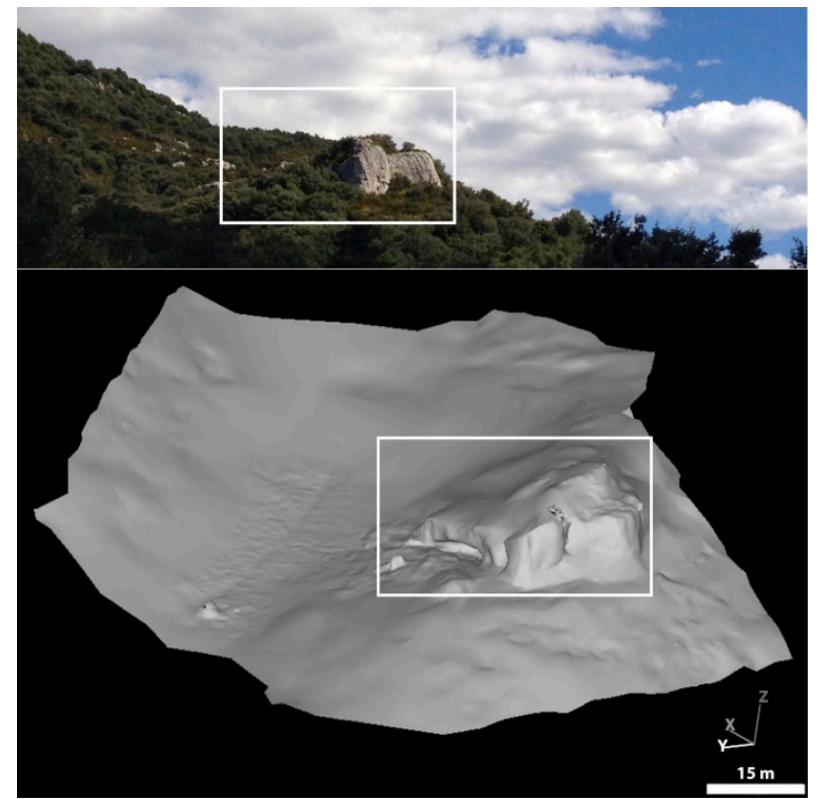

SOM Figure S1. 3D scan of Grotte Mandrin and hill. North aligned with Yaxis. The rock shelter is open towards the North. Picture on the way up to the site, taken facing the Southeast.

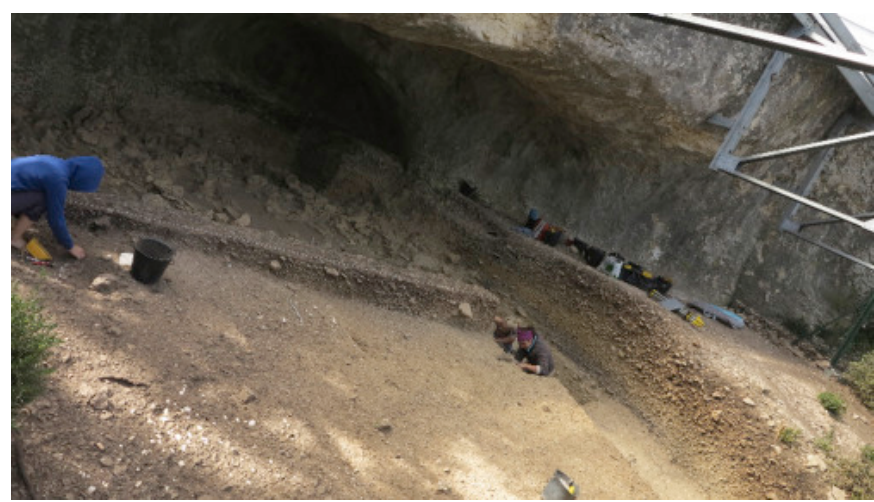

SOM Figure S2. Picture of Grotte Mandrin rock shelter, taken facing the Southwest.

\section{A.2. Nature of black deposits}

Black deposits trapped in carbonates can have several origins. Dark staining of carbonates can be due to metallic oxides, organic compounds dissolved in groundwater, algae, lichens, and combustion residues from domestic or wild fires.

To investigate the origin of the black deposits on the Grotte Mandrin clasts, SEM and X-ray microprobe analyses were performed on five different samples. No trace of manganese could be detected in the samples with X-ray microprobe (SOM Fig. S6). SEM analysis also shows that the soot deposit is well mixed into the calcareous coating, since there is no significant difference in elemental composition between the black laminae and the carbonate laminae. Other analyses on the same type of material had highlighted the lack of carbon-rich soot formation distinguishable from carbonates (Martínez-Pillado et al., 2010, 2014). To the contrary, soot is well cemented in them (Gradziński, 2007; Bonneau et al., 2011), as small balls (Tomasini et al., 2012) imbricated between crystals of calcium carbonate (SOM Fig. S3). Nevertheless, other metallic oxides can be identified. Indeed, iron oxides are present, but in the form of hematite. They appear in reflected light as red films, 


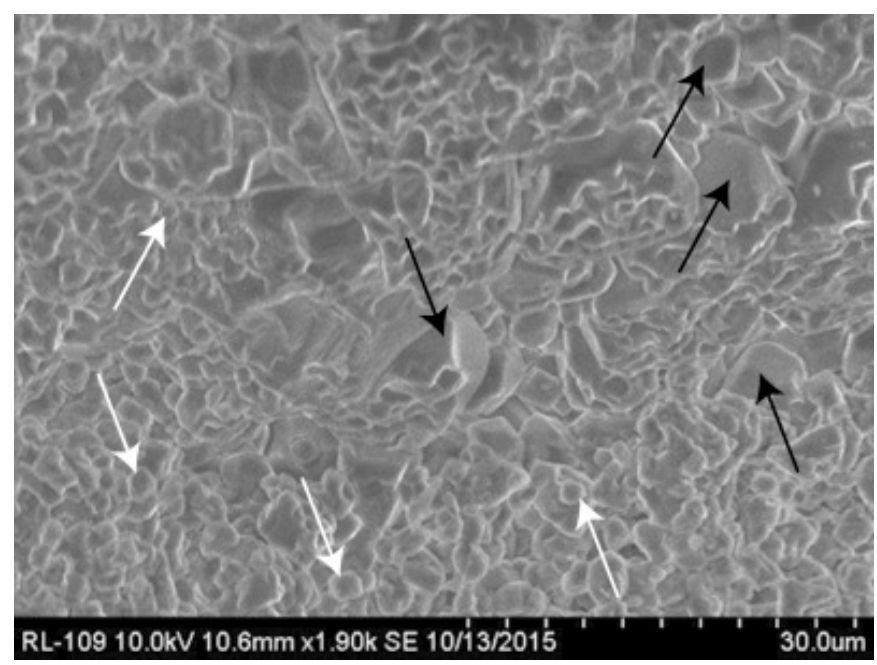

SOM Figure S3. Back-scattered electron image of the sample. Observations show that the carbon is mostly in the form of tiny balls, about $2 \mu \mathrm{m}$ in diameter, which is a common form for soot (Tomasini et al., 2012). White arrows $=$ some representative tiny balls of soot, black arrows $=$ some representative calcite crystals. The upper and lower parts of the image show more soot than the central part, where carbonate crystals are best seen.

which are easily distinguished from the black films observed at the Grotte Mandrin.

The black films are neither metallic oxides nor lichens, algae, or organic compounds dissolved in groundwater, as shown by Raman spectra. These latter were carried out at the Laboratoire de caractérisation des matériaux, Université de Montréal, Canada. An InVia microspectrometer Raman was used with 514 and $785 \mathrm{~nm}$ lasers and $\mathrm{x} 50$ long-focal objectives. Spectra recorded with the $785 \mathrm{~nm}$ laser show peaks at 230, 283, and $1085 \mathrm{~cm}^{-1}$, which are linked to the presence of calcite (SOM Fig. S4), and two broad peaks at 1330 and $1595 \mathrm{~cm}^{-1}$, which are identified as carbon bonds from the soot (SOM Fig. S5-Bonneau et al., 2012). This kind of spectrum is comparable to those observed on charcoals, with D (defect) and $\mathrm{G}$ (graphite) bands (Deldicque et al., 2016). Interestingly, the peaks of calcite were also found in the soot layer, showing an impregnation of the precipitating calcite by the soot.

It is now obvious that the black films observed in the parietal crusts of the Grotte Mandrin are soot deposits. The final question concerns the anthropogenic nature of the fires that left the soot traces. First of all, many hearth structures have been identified in different archaeological levels of the cavity (Fig. 2). In the case of wild fires, it is logical to expect them during dry seasons. However, soot films are here observed in thin sections indifferently in dark compact laminae (DCL) and white porous laminae (WPL), while DCL (sparitic calcite laminae) are formed during periods of hydric excess. In addition, soot films are numerous, repeated, and not occasional. This last point does not constitute strong evidence in itself, but is more consistent with the soot layers originating from anthropogenic fires rather than natural wild fires.

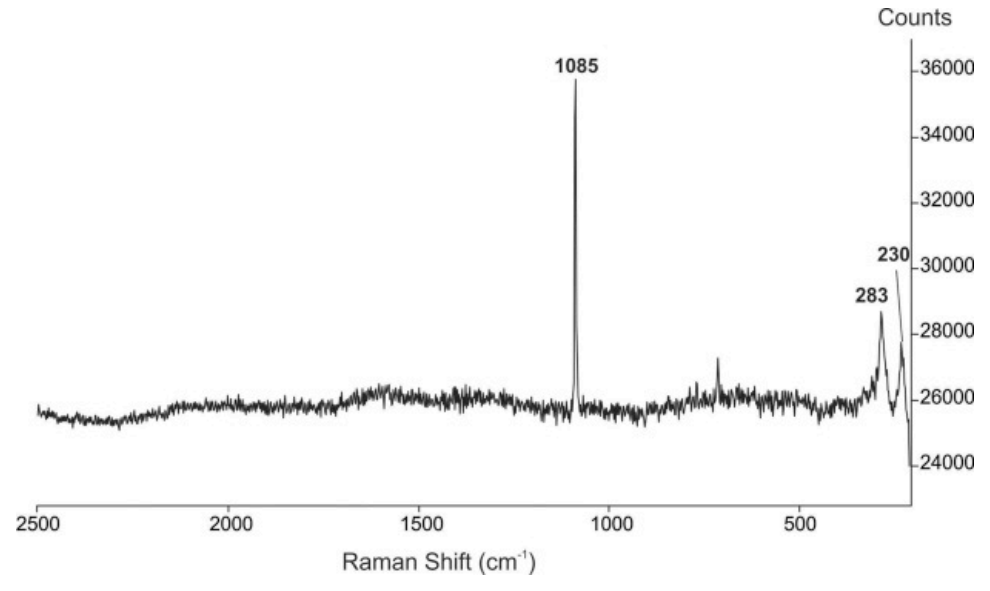

SOM Fioure S4. Raman snectrum recorded on the white "clean" laver

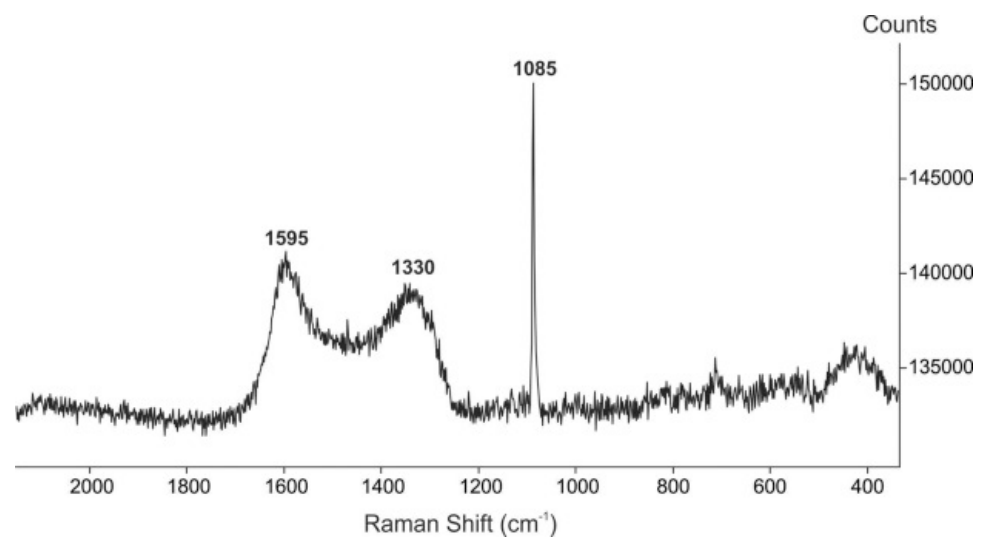

SOM Figure S5. Raman spectrum recorded on the black layer. 


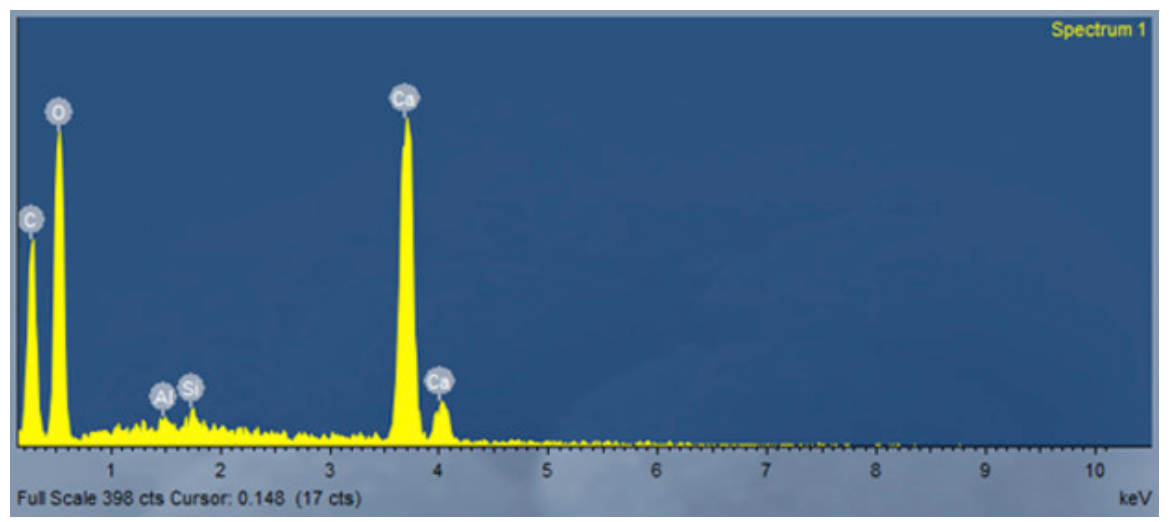

SOM Figure S6. EDS spectrum of the soot layer.

\section{A.3. Example of individual sequences correlation: graphical} building of a synthetic sequence (combination)

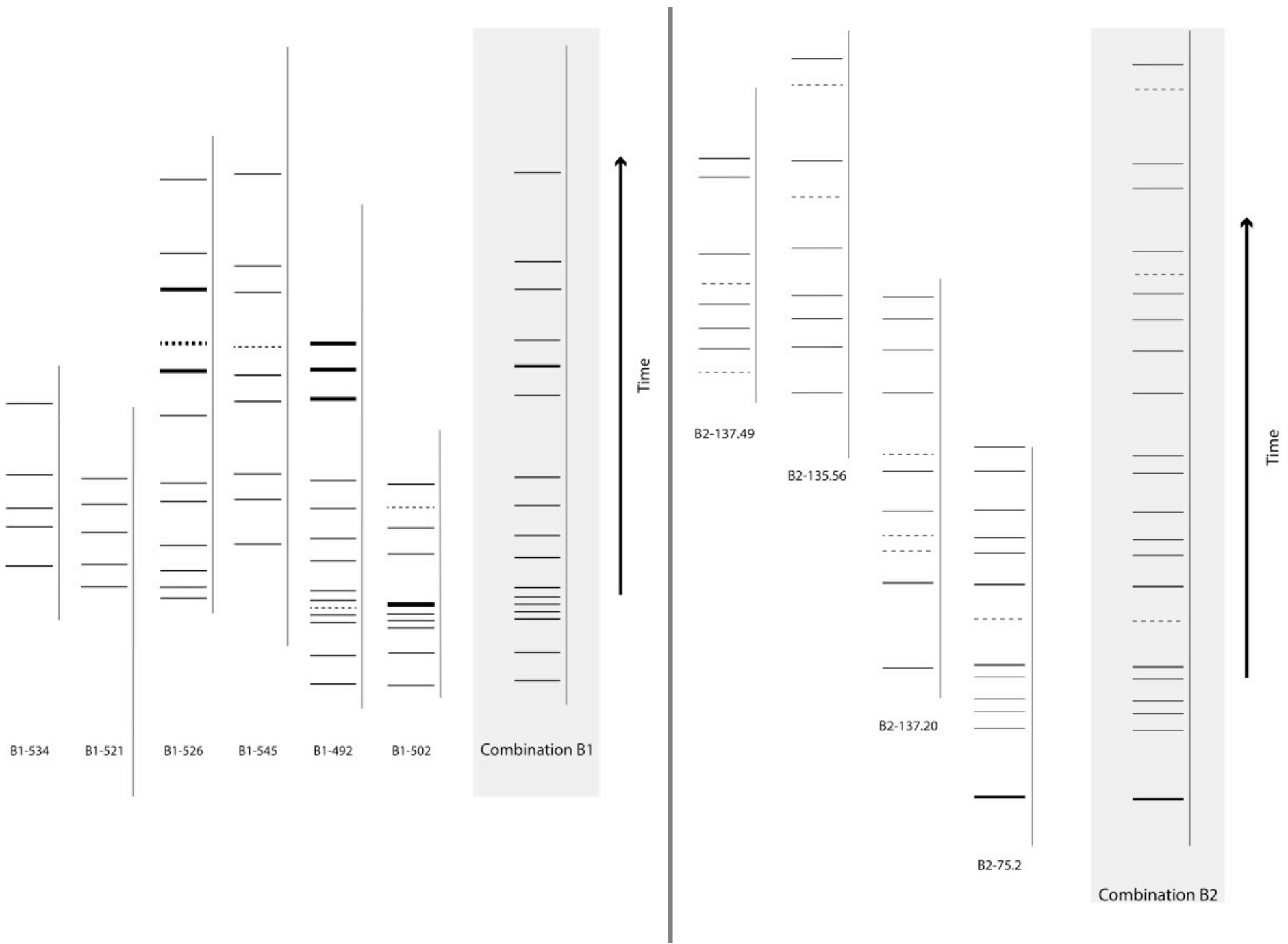

SOM Figure S7. Building of synthetic occupations chronicles for levels B1 (7a) and B2 (7b) 


\section{A.4. Micro-chronology}

The concept of micro-chronology is central in archaeology but can be very relative. The term is generally used when any increase in temporal resolution is sought, whether absolute or relative (see for example Kowalewski and Williams, 1989; Brochier, 2002; Stojanowski et al., 2006). It can then, according to the methods and disciplines, refer to seasonal, annual, or decadal measures of time. Soot deposits trapped in concretions are traces of human activities. This is true in all geographic areas and all periods. Micro-chronological study of the black films of soot trapped in concretions allows us to chronicle the successive occupations of caves and rock-shelters with exceptional resolution, to the point where we can document annual occupation, or even seasonal occupations in the best cases.

Examples of micro-chronological studies exist for more recent periods than the one presented in our paper. For example, as noted above, the analysis of the Balma de la Margineda (Andorra) from the Azilian period was one of the first successful attempts to use soot deposits to document microchronology in a site (Brochier, 1997, 2008). Likewise, Genty et al. (1997b) identified at least 73 summers of visits by tourists to Han-sur-Lesse cave (Belgium) in the XIX ${ }^{\text {th }}$ century, through the study of carbonaceous deposits trapped in two stalagmites.

The idea of micro-chronology was already widely discussed in the $90 \mathrm{~s}$, and the word can be found in various publications and disciplines, though not always with the same time resolution. It has been used in literature research (Levaillant 1982; Saminadayar-Perrin 2008), ceramics seriation (Kowalewski and Williams, 1989), paleo-genetics (Stojanowski et al., 2006), individual visits to a site (Kavur, 2008), sequences of wall plasters (Matthews, 2005), and geoarchaeological studies (Brochier, 1997, 2002).

By comparison to micro-chronology, we may also refer to meso-chronology and macro-chronology. Micro-chronology refers to a high temporal resolution, from sub-annual to decennial. It can be compared to a "human life or ethnological timescale." Meso-chronology is more of an "archaeological timescale," with a resolution from century to millennia. Finally, macro-chronology refers to the geological timescale with a resolution from thousands of millennia to billions of years.

The method used in this research is based on the study of micro-stratigraphical concretions trapping soot and, in this precise case, of parietal carbonated crusts of Grotte Mandrin. The micro-stratigraphical observations allow ordering of events (in our case soot deposition, carbonates precipitation during "wet" or "dry" periods), but the appreciation of time between the various events is not (and cannot be) clearly related to absolute time. Micro-stratigraphy provides a relative chronology (see for example Watchman, 2000). It is here interpreted through a micro-chronological approach, which orders events on a time scale (floating) linked explicitly with time. In the best case, the temporal resolution is known, controlled, or precisely estimated, and the resolution of the DCL/WPL pairs is generally infra-annual as seen in the formation of modern deposits.

A concretion recording soot deposits is a powerful microchronological tool. In the worst case, it documents the sequence of soot films and thereby the minimum number of occupations in an archaeological layer. When DCL/WPL doublets are proved to be annual, they provide potentially critical data on the frequency, seasonality, and even the minimum length of occupation of a cave or rock shelter.

\section{A.5. Micro-chronology and absolute radiocarbon chronology agreement tests}

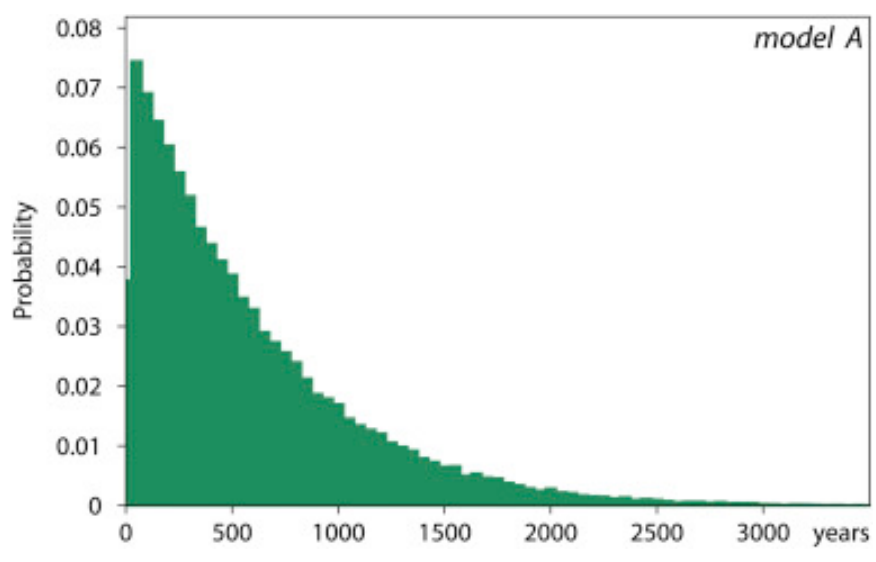

SOM Figure S8. Model A. Posterior probability distribution for the time elapsed from the end of $\mathrm{C}$ to the beginning of $\mathrm{B}$ occupations.

Eight radiocarbon determinations, all from well preserved bone collagen, have been obtained by Tom Higham (Higham et al., 2014:Supplementary information, Tables S12 and S13) from archaeological levels B2, B3, and C. We have analyzed two simple chronological models using BCal on-line Bayesian radiocarbon calibration tool (Buck et al., 1999) and IntCal13 atmospheric calibration curve (Reimer et al., 2013).

The first one (Model A-SOM Fig. S8) is a simple two non-abutting phases model in which the events are not ordered. Four determinations belong to the first C phase (OxA 21690, OxA X-2286-10, OxA X-2286-13, and OxA X-2286-14) and four determinations belong to the second B3-B2 phase (OxA 21691, OxA 22121, OxA 21685, and OxA 22120). We want to learn about the duration of the alleged hiatus, which separates archaeological unit C from units B3-B2. According to our micro-chronological results, the modeled duration should include very short (decennial) durations as a possibility.

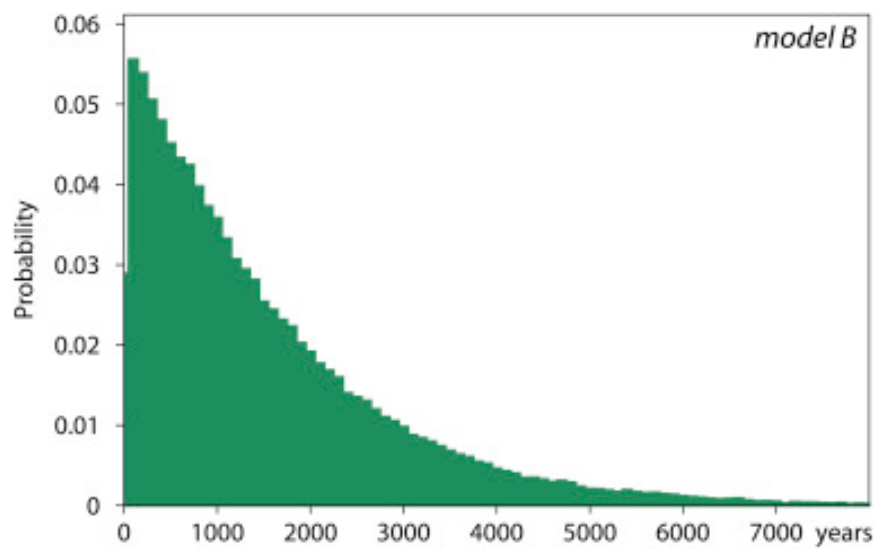

SOM Figure S9. Model B. Posterior probability distribution for the duration of $\mathrm{B} 3$ and $\mathrm{B} 2$ occupations.

The analysis shows that two of the eight determinations are outliers in this model (i.e., they need a shift on the radiocarbon scale to be consistent with the other determinations): OxA X2286-10 and OxA 21691. For an a priori probability of 0.05 to 
be an outlier assigned to all the determinations, the a posteriori probabilities that OxA X-2286-10 and OxA 21691 need to be shifted are 0.53 and 0.19 , respectively. The chronological information arising from them is given less weight and they do not need to be removed (Buck et al., 2003).

The highest posterior density region (HPD 95\%) of time duration of the alleged hiatus between $\mathrm{C}$ and B3-B2 units appears to be bracketed between 0 and 1550 years (SOM Fig. S8). It includes 0 and very short decennial durations and thus is not in conflict with our micro-chronological results. Multiple runs with different initial parameters show that results of these simulations are reproducible. The upper bounds of HPDs does not differ more than one-tenth of standard error from conventional radiocarbon ages. Null duration lower bound is included in all HPDs.

Our micro-chronological results concerning the short-term recurrence of occupations in the rock-shelter from $\mathrm{C}$ to $\mathrm{B} 1$ leads us to construct a more likely chronological model (Model B-SOM Fig. S9). The only difference from Model A is that the two phases are now considered as abutting.

The analysis of this model shows the same two outliers (posterior probabilities to be outliers of 0.39 and 0.17 , respectively). It allows us to estimate the duration of B3-B2 archaeological units. The HPD region (95\%) of time duration is bracketed between 0 and 3490 years (SOM Fig. S9). As above, this HPD includes short decennial durations as a possibility, which are not inconsistent with our results.

\section{A.6. Lithic technologies at the Grotte Mandrin...}

... Layers $F$ and E: rhodanian Quina Mousterian and Neronian industries Layer $\mathrm{F}$ records a classic Mousterian industry (Slimak, 2004) based on Discoid flaking to produce large and thick side-scrappers. This layer F lithic industry is defined as a rhodanian Quina Mousterian (Combier, 1967; Le Tensorer, 1981; Bordes, 1984; Slimak, 1999, 2002), for which the Mandrin F layer represents one of the best preserved units. Such Mousterian industries are mainly found in the Rhône valley and its tributaries: Gard, Gardon, and Ardèche, with a current northern limit with the Grand Champ open air site in the gorges of the Loire river (Slimak, 2008a). Overlying this rhodanian Quina Mousterian assemblage, layer E is attributed to the Neronian, a Middle to Upper Paleolithic transitional group dated around $50 \mathrm{ky}$ cal. BP (Slimak, 2004; Higham et al., 2014). The Neronian was first individualized by Jean Combier based on the Grotte de Néron, Grotte du Figuier, and Abri du Maras industries, and was then perceived as an evolved Mousterian, with a very high proportion of Upper Paleolithic tools, a parallel culture of the Châtelperronian for the Rhône valley (Combier, 1967, 1990). It has been fully described, defined, and understood primarily based on Mandrin layer E industries (Slimak, 2004). Contrary to traditional Mousterian industries, Neronian lithic production is oriented toward the manufacture of standardized points and micropoints that commonly can reach a centimetric (and even infra-centimetric) maximal size. These points are obtained by a systematic unipolar blade and bladelets debitages where some (micro)points are regularly produced. Approximately $30 \%$ of the end-product are micropoints having a maximal length below $30 \mathrm{~mm}$. Mandrin E layer provided more than a thousand standardized points, making this layer richer in points than all
Middle Paleolithic sites of Europe combined (Metz, 2015). More important, their size and technical standardization share no technical relation with any other Middle Paleolithic industry in Eurasia. Specific flake production is not recorded in these technical systems. Neronian is also characterized by its fossile directeur (type-fossil): the Soyons Point, defined in 1955 by Jean Combier in the eponymous Grotte de Néron, in Soyons (Combier, 1955; Bordes, 1961). Soyons points are Levallois points modified by a convergent and semi-abrupt thin and inversed retouch. Neronian groups made a systematic selection of high quality raw material coming from a large area, including both banks of the Rhône River (Slimak, 2004). The Neronian assemblage has technically a high level of complexity, requiring a considerable precision in the technical processes and allowing systematic manufacturing of these points (Slimak, 2008b). These technologies are technically very modern and based on the production of standardized microlithic points used as mechanically propelled weapons (Metz, 2015; Metz and Slimak, in prep.). It shares no technical traits with the underlying rhodanian Quina Mousterian level (layer F).

From layer $\mathrm{C}$ to level $\mathrm{B} 1$ : post-Neronian and Protoaurignacian industries The Grotte Mandrin is the only site revealing the existence of post-Neronian Mousterian occupations. Indeed, in the other main late Mousterian sequences of the Rhône valley, the most recent stratigraphic layer contains the Neronian industry (Mousterian sequences of Moula, Figuier, Maras, Néron-Slimak, 2004, 2008a). The post-Neronian Mousterian industries represent the last expressions of the Mousterian in the area. They directly precede the presence of the first Aurignacian assemblages in that part of Europe. They show a discontinuity with the technical systems of the Neronian, expressed in lithic technical systems, territories, and raw material choices. These late Mousterian assemblages are mainly based on flakes produced from Levallois and Discoid flaking to create blanks for typically Mousterian tools. The raw materials employed are strictly local and only come from the east bank of the Rhône. Exotic rocks of the Neronian were no longer used (Slimak, 2008b).

In the Grotte Mandrin, the post-Neronian phase can be subdivided into two distinct, technically well differentiated sets The first is the post-Neronian I (layer D). This industry is based on the production of small flakes essentially obtained from secondary flaking of black exotic flints coming from the prealp mountains, $70 \mathrm{~km}$ northeast of the Grotte Mandrin. Further details are not provided here, since this article does not focus on post-Neronian I culture. The second set is the post-Neronian II (layer C and levels B3 and B2). The assemblages are clearly distinguished from both the Neronian and the post-Neronian I. The technological systems are focused on the manufacture of large flakes used to produce large sidescrapers, fairly typical of the Mousterian. This industry uses a large spectrum of flaking technologies, dominated by Levallois and Discoid flaking (Slimak, 2003), but also using large laminar and micro-laminar technologies in low proportions. Flakes are used to produce a large variety of scrapers dominated by transversal scrapers showing a rectilinear delineation. Each post-Neronian II level also contains some original scrapers retouched to obtain a 
perfect $90^{\circ}$ angle, unknown in any other Mousterian industry (Slimak, 2004). The post-Neronian II occupations can be considered as the last occurrence of the Mousterian in Mediterranean France (Slimak, 2008b; Higham et al., 2014).

The Protoaurignacian lithic production at the Grotte Mandrin (level B1) is focused on the production of long and straight bladelets. Different categories of bladelets can be technically distinguished and illustrate different technical processes for their production. Some large blades are also present but the main technical trait of the Protoaurignacian is its primary focus on regular bladelets production obtained by distinct "schémas opératoires" (Slimak et al., 2002, 2006). The bladelets themselves provide evidence for different processes used to obtain different sizes and shapes of bladelets. Larger blades are produced by a less standardized system of production and show no technical continuity with bladelet production. None of these Protoaurignacian bladelets come from the reduction of blade cores. Contrary to bladelet production, most larger laminar blanks were produced from a fairly simple production scheme showing minimal technical investment. The procurement territory of siliceous rocks used in the Protoaurignacian is mainly local, comparable with the one of post-Neronian II. It illustrates an exploitation of a pretty limited territory around the rock shelter in comparison with the Neronian. However, in contrast with post-Neronian II, Protoaurignacian toolmakers were hyper-selective in their raw material choices, using only the best quality local flint-nodules. The Protoaurignacian raw material selection is highly systematic and closely aligned to their technological ends, just like in the Neronian (Slimak, 2008b). It is possible to underline in a diachronic approach, some clear technical links between the Neronian and the Protoaurignacian, particularly with regard to standardized bladelets, of the presence of triangular and acute morphology, and even common technical processes for their manufacture (Slimak, 2004). On the contrary, postNeronien II and Protoaurignacian industries are absolutely distinct, share no technical traits, and show no technical influences shared between them. If things are much more subtle with the Neronian, it makes clear that the very last Mousterian expression, represented in that geographic area by the post-Neronian II, have, technically speaking, no relation to the Protoaurignacian groups

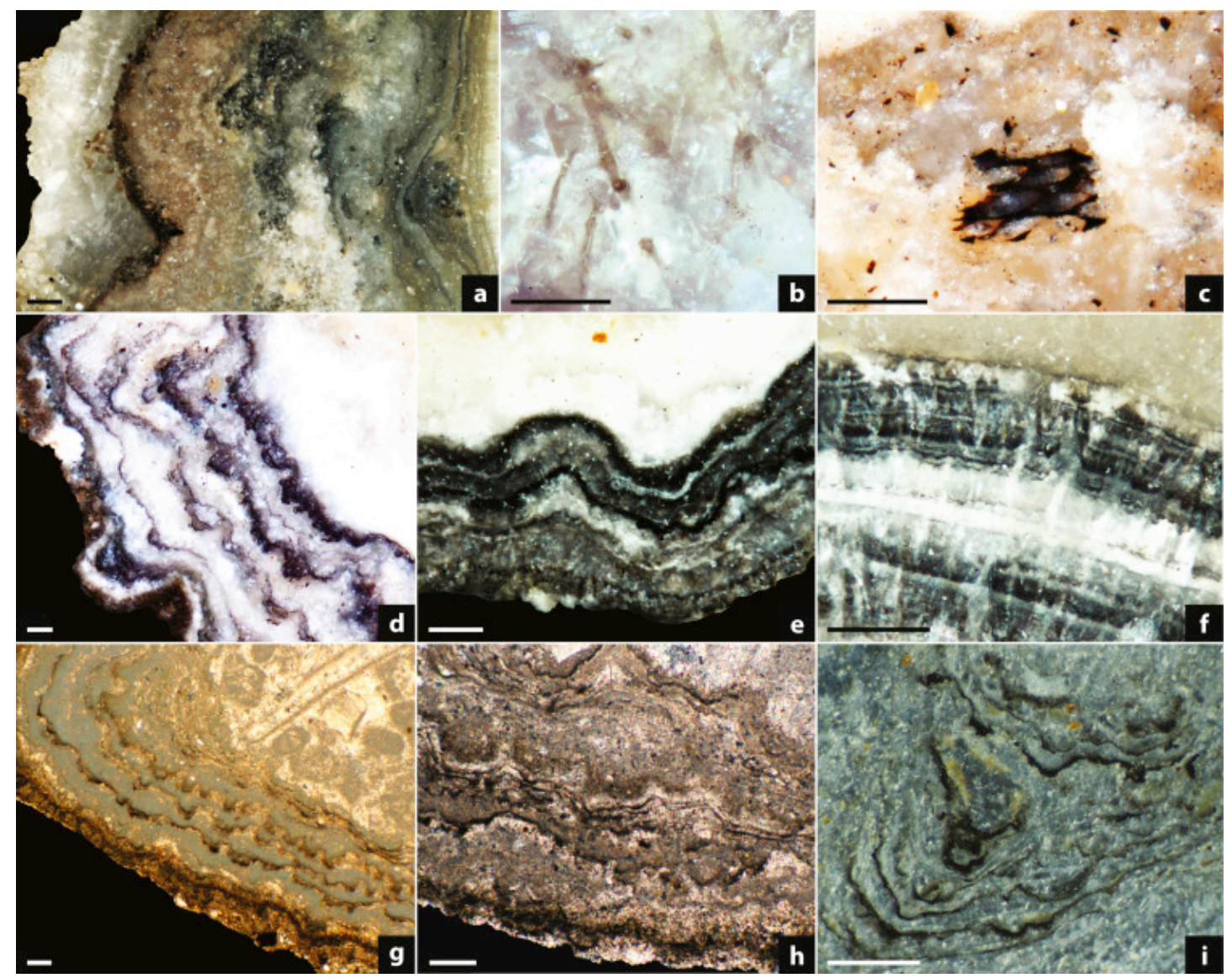

SOM Figure S10. Supplementary figures. For all pictures: scale $=100 \mu \mathrm{m}$

a. Polished section, x100, RL. From left to right: first is a sparitic concretion that formed on the ground after the clast's fall; second is a brownish black band of sediment (mainly micro-charcoals) trapped between this sparitic crust and the parietal crust; third is the parietal carbonated crust trapping soot films. Note the color difference between the soot and the black sediment. The pinkish coloration of the external part of the parietal crust is due to metallic oxides.

b. Polished section, x200, RL. Mycelial hyphae in sparitic calcite.

c. Polished section, $\mathrm{x} 200$, RL. Micro-charcoals trapped in parietal carbonated crust. The biggest one, in the picture's center, is $\sim 140 \mu \mathrm{m}$ long.

$\mathrm{d}$ to $\mathrm{i}$ are examples of polished and thin sections:

d. Polished section, $\mathrm{x} 50, \mathrm{RL}$

e. Polished section, $\mathrm{x} 100, \mathrm{RL}$.

f. Polished section, $\mathrm{x} 200, \mathrm{RL}$.

g. Thin section, x50, RL + XPL. Combination of XPL + RL enhances the discrimination of micrite and micro-sparite, in order to observe more easily the WPL/DCL doublets. Note that lamination disappears for the last micrometers of the crust, where the calcite is mostly micro-sparitic. This is probably due to post-depositional dissolution/recrystallization.

h. Thin section, $\mathrm{x} 100$, XPL. Note that lamination disappears for the last micrometers of the crust. This is probably due to post-depositional dissolution/recrystallization.

i. Thin section, $\mathrm{x} 200$, RL. 


\section{References only in SOM}

Bonneau, A., Brock, F., Higham, T., Pearce, D.G., Pollard, A.M., 2011. An improved pretreatment protocol for radiocarbon dating black pigments in San rock art. Radiocarbon 53, 419-428.

Bonneau, A., Pearce, D.G., Pollard, A.M., 2012. A multi-technique characterization and provenance study of the pigments used in San rock art, South Africa. J. Archaeol. Sci. 39, 287-294.

Bordes, F., 1961. Typologie du Paléolithique ancien et moyen, Publication de l'Institut de Préhistoire de l'Université de Bordeaux ed. Imprimeries Delmas, Bordeaux.

Buck, C.E., Christen, J.A., James, G.N., 1999. BCal: an on-line Bayesian radiocarbon calibration tool. Internet Archaeol. 7, http://dx.doi.org/10.11141/ia.11147.11141.

Buck, C.E., Higham, T.F.G., Lowe, D.J., 2003. Bayesian tools for tephrochronology. The Holocene 13, 639-647.

Combier, J., 1955. Pointes levalloisiennes retouchées sur la face plane (Pointes, type Soyons). Bull. Soc. Prehist. Fr. 52, 432-434.

Deldicque, D., Rouzaud, J.-N., Velde, B., 2016. A Raman-HRTEM study of the carbonization of wood: A new Raman-based paleothermometer dedicated to archaeometry. Carbon 102, 319-329.

Kavur, B., 2008. Implementing, writing and thinking palaeolithic archaeology in Slovenia. Ann.: anali Koprskego primorja in bližnjih pokraijin: annali del Litorale capodistriano e delle regioni vicine. Ser. Hist. Sociol. 18, 1-14

Kowalewski, S.A., Williams, M., 1989. The Carroll Site: Analysis of 1936 Excavations at a Mississippian Farmstead in Georgia. Southeast. Archaeology 8, 46-67.

Levaillant, J., 1982. Écriture et génétique textuelle-VALERY à l'œuvre. Presses Universitaires de Lille, Lille.

Matthews, W., 2005. Micromorphological and microstratigraphic traces of uses and concepts of space. In: Hodder, I. (Ed.), Inhabiting Catalhöyük: Reports from the 1995-1999 seasons. McDonald Institute for Archaeological Research, Cambridge, pp. 355-398.

Reimer, P.J., Bard, E., Bayliss, A., Beck, J.W., Blackwell, P.G., Bronk Ramsey, C., Buck, C.E., Cheng, H., Edwards, R.L., Friedrich, M., Grootes, P.M., Guilderson, T.P., Haflidason, H., Hajdas, I., Hatté, C., Heaton, T.J., Hoffmann, D.L., Hogg, A.G., Hughen, K.A., Kaiser, K.F., Kromer, B. Manning, S.W., Niu, M., Reimer, R.W., Richards, D.A., Scott, E.M., Southon, J.R., Staff, R.A., Turney, C.S.M., van der Plicht, J., 2013. IntCal13 and Marine13 Radiocarbon Age Calibration Curves 0-50,000 Years cal BP. Radiocarbon 55, 1869-1887.

Saminadayar-Perrin, C., 2008. Qu'est-ce qu'un événement littéraire au XIXe siècle? Publications de l'Université de Saint-Étienne, Saint-Étienne.

Slimak, L., 2003. Les débitages discoïdes moustériens: évaluation d'un concept technologique. In: Peresani, M. (Ed.), Discoid lithic technology: advances and implications. British Archaeological Reports (BAR), Oxford, pp. 3365 .

Slimak, L., 2008a. Artisanats et territoires des chasseurs moustériens de Champ Grand. MMSH, Aix-en-Provence.

Stojanowski, C.M., Schillaci, M.A., 2006. Phenotypic approaches fo understanding patterns of intracemetery biological variation. Am. J. Phys. Anthropol. 131, 49-88.

Tomasini, E., Siracusano, G., Maier, M.S., 2012. Spectroscopic, morphological and chemical characterization of historic pigments based on carbon. Paths for the identification of an artistic pigment. Microchem. J. 102, 28-37.

Watchman, A.L., David, B., McNiven, I.J., Flood, J.M., 2000. Microarchaeology of Engraved and Painted Rock Surface Crusts at Yiwarlarlay (the Lightning Brothers site), Northern Territory, Australia. J. Archaeol. Sci. 27, 315-325.

\section{Appendix A. Supplementary Online Material}

Supplementary online material related to this article can be found at http://dx.doi.org/10.1016/j.jhevol.2017.07.016. 